\title{
"DE LO QUE YO EL INFRASCRIPTO ESCRIBANO DOY FE». LOS ESCRIBANOS DE LA VILLA DE ALBACETE DURANTE EL SIGLO XVIII
}

\author{
RAMÓN CÓZAR GUTIÉRREZ \\ Universidad de Castilla-La Mancha
}

Fecha de recepción: octubre de 2009

Fecha de aprobación: diciembre de 2009

\begin{abstract}
«Dos oficios hallo yo que a mi parecer habían de ejercerse por hombres de buen linaje y de satisfacción: el uno es el del boticario, de cuya sola confianza dependen las vidas de los hombres, y el otro el del escribano, de quien dependen vidas, honras $\mathrm{y}$ haciendas, porque el uno con la pluma, y el otro con la purga matan callando, más que un ejército de enemigos combatiendo».

Castillo De Bovadilla, Politica para Corregidores...
\end{abstract}

En nuestra pretensión de analizar las redes de relación de la oligarquía municipal castellana durante la Edad Moderna ${ }^{1}$, no hemos querido limitarnos al estudio de los regidores como «bloque de poder» y sus vínculos horizontales intra-oligárquicos, sino que también nos hemos sumergido en la búsqueda de la existencia de vínculos verticales que permitan analizar la conexión de los poderosos con las capas inferiores de la sociedad, para mejorar la comprensión del modo en que se ejerce en los núcleos rurales de la Monarquía Hispánica la dominación política y social. ${ }^{2}$ Por ello, presentamos en

1. Este trabajo ha sido realizado en el marco del Proyecto de Investigación El primer reformismo borbónico en el espacio mediterráneo: construcción de fidelidades dinásticas, circulación de prácticas políticas e implantación de modelos administrativos (1700-1759), financiado por el Ministerio de Educación y Ciencia (código HUM2005-06310), siendo su investigador principal el Dr. Francisco Javier Guillamón Álvarez. Las abreviaturas empleadas corresponden a: AGS (Archivo General de Simancas); AHN (Archivo Histórico Nacional); AHP (Archivo Histórico Provincial).

2. Imízcoz Beunza señala que se han dado dos aplicaciones historiográficas de los llamados vínculos sociales. La primera y más tradicional es la del estudio de la oligarquía como «bloque de poder» más o menos 
este trabajo, el estudio de un grupo profesional que permanece en contacto permanente con la élite, actuando como «intermediarios del poder» entre ésta y la mayoría iletrada, tanto en el ámbito público como en el privado y particular. Un grupo intermedio de los más activos en cuanto a su movilidad dentro de la sociedad, ${ }^{3}$ pues en su gran mayoría, se verán favorecidos de esa «agradable y productiva sensación de poder» de la que gozaban otros privilegiados. Nos estamos refiriendo a los escribanos, un conjunto de personajes con los que, junto a justicias y regidores, queda configurado el aparato burocrático permanente del ayuntamiento durante gran parte del Antiguo Régimen. ${ }^{4}$

Nuestro propósito, se centra, por un lado, en conocer los aspectos técnicos de su actividad -definición, formación, retribuciones, tipología, formas de acceso y mecanismos de transmisión- $y$, por otro, en definir socialmente a este grupo profesional y analizar sus influencias y relaciones con los poderosos. Para todo ello nos valdremos de la documentación municipal y de protocolos notariales ${ }^{5}$ perteneciente a un territorio y un conjunto poblacional concreto, entre el mundo rural y el mundo urbano, la villa de Albacete, en un tiempo, el siglo XVIII, en el que gracias a su emplazamiento y ventajas geográficas - punto neurálgico en las comunicaciones entre Andalucía, Levante y la Meseta-, el crecimiento agrícola -fuerte proceso roturador de montes y superficies incultas-, el emergente comercio -auspiciado por las ferias-y el traspaso a favor de la villa de la primacía en las redes sociales y económicas de los lugares cercanos, permitió que Albacete se convirtiera en una de las principales poblaciones del extremo oriental de la llanura manchega. ${ }^{6}$

separada del resto de la sociedad. Y la segunda se centra en la búsqueda de la existencia de vínculos verticales, que permitan analizar la conexión de los poderosos con las capas inferiores de la sociedad. IMÍzCOZ BEUNZA, J.M. «Comunidad, red social y elites. Un análisis de la vertebración social en el Antiguo Régimen», en Imízcoz BeUnZA (dir): Elites, poder y red social. Las elites del País Vasco y Navarra en la Edad Moderna. Bilbao, 1996.

3. Aranda PÉRez, F.J.. Poder y poderes en la ciudad de Toledo. Gobierno, Sociedad y Oligarquías en la Edad Moderna. Cuenca, 1999. p. 131.

4. A partir de 1766 se ampliaría el número de sillones consistoriales con la llegada de los diputados del común y síndicos personeros.

5. Sobre la importancia de estas fuentes documentales véase EIRAS ROEL, A. et alii: La historia social de Galicia en sus fuentes de protocolos. Santiago de Compostela, 1981; y LóPEZ-SALAZAR PÉrEZ, J.: «Los protocolos notariales. Fuentes documentales para la Historia Moderna», en Actas del Congreso La Investigación y las Fuentes Documentales de los Archivos. T.I. Guadalajara, 1996.

6. Para profundizar en este sentido véase CózAR GuTIÉRREZ, R.: Gobierno municipal y oligarquías. Los oficios públicos de la villa de Albacete durante el siglo XVIII. Ediciones UCLM. Cuenca, 2005; y GóMEZ CARRASCO, C.J.: Entre el mundo rural y el mundo urbano. Familia, parentesco y organización social en la villa de Albacete (1750-1808). Albacete, 2007. 


\section{EL OFICIO DE ESCRIBANO: TIPOLOGÍA, FORMAS DE ACCESO, MECANISMOS DE TRANSMISIÓN}

La importancia de la figura del escribano ha sido resaltada en los últimos años por algunos autores ${ }^{7}$. Durante el Antiguo Régimen y hasta bien entrado el siglo XIX, la inmensa mayoría de la población, como ha señalado Bouza Álvarez ${ }^{8}$, era iletrada, por lo que debía recurrir a la minoría letrada si quería expresar o dejar constancia de algo

7. Entre las publicaciones encontradas podemos citar los clásicos trabajos de Arribas Arranz («Los escribanos públicos en Castilla durante el siglo XV», en Centenario de la Ley del Notariado, Madrid, 1964. pp. 169260.), Corral García (El escribano de concejo en la Corona de Castilla (siglos XI al XVII), Burgos, 1987), Álvarez-Coca González («La figura del escribano», en Boletín Anabad. XXXVII, 4. 1987),y Martínez Gijón («Estudios sobre el oficio de escribano en Castilla durante la Edad Moderna», en Centenario de la Ley del Notariado. Madrid, 1964. pp. 265-340), orientados hacia la actividad administrativa en la corona de Castilla; otros con un tratamiento más local, como el de Pozas Poveda («Aproximación al estudio del oficio de escribano público del número de la ciudad de Córdoba en la primera mitad del siglo XVIII», Axerquía, 15, (1985), pp. 92-123), Gómez Navarro («Un ensayo de microanálisis social: los escribanos cordobeses ante la muerte (1690-1833)», en La Burguesía Española en la Edad Moderna, T. II, Valladolid, 1996. pp. 1.071-1.087), Ostos Salcedo («Los escribanos públicos de Córdoba en el tránsito de la Edad Media a la Edad Moderna. Una aproximación» en OsTOS SALCEDO, P. y PARdo RodríGUEZ, M.L. (eds.): El notariado Andaluz en el tránsito de la Edad Media a la Edad Moderna. Sevilla, 1996), y Extremera Extremera («Los escribanos públicos de Córdoba en la Edad Moderna. Una aproximación sociológica», en Axerquía. 2002. n 19. pp. 97-109) para la ciudad de Córdoba, Rábade Obradó (Orígenes del notariado madrileño: los escribanos públicos en el siglo XV. Madrid, 2001) y Alvar Ezquerra et alii ( «Los Escribanos del Concejo de Madrid (1561-1598)» Cuadernos de Historia de España ene./dic. 2005, vol.79, p.167-201) para Madrid, Noguera de Guzmán para Barcelona (Los notarios de Barcelona en el siglo XVIII, Barcelona, 1978), Marchant Rivera para Málaga (Los escribanos públicos en Málaga bajo el reinado de Carlos I. Málaga, 2002), González Cruz para Huelva (Escribanos y notarios en Huelva durante el Antiguo Régimen (1701-1800): (la historia onubense en sus protocolos notariales). Huelva, 1991), Del Arco Moya para Jaén («Escribanías y escribanos del número de la ciudad de Jaén», en Boletín del instituto de estudios Giennenses. N 153. 1994); De la Obra Sierra para Granada («Aproximación al estudio de los escribanos públicos del número en Granada (1487-1520)», en OSTOS SALCEDO y PARDO RodRíGuez: El notariado Andaluz... op. cit.); Pardo Rodríguez para Sevilla («El notariado de Sevilla en el tránsito a la modernidad», en OSTOS SALCEDO y PARDO RODRÍGUEZ: El notariado andaluz... op. cit.) y algunos otros que reflejan su implantación en ultramar, como el de Bravo Lozano e Hidalgo Nuchera (De indianos y notarios. Madrid, 1995), Guajardo-Fajardo Carmona (Escribanos en Indias durante la primera mitad del siglo XVI. Madrid, 1995) o Dougnac Rodríguez («El escribano de Santiago de Chile a través de sus visitas en el siglo XVIII» en Rev. estudios histórico-jurídicos, 1997, no.19, p.49-93). En los últimos años hay que destacar los trabajos de Extremera Extremera («Los escribanos de Castilla en la Edad Moderna. Nuevas líneas de investigación», en Chronica Nova. № 28, 2001; «Los escribanos públicos de Córdoba en la Edad Moderna. Una aproximación Sociológica», Axerquia, n 19. 2001; «La pluma y la vida. Escribanos, cultura escrita y sociedad en la España Moderna (Siglos XVI-XVIII)» en LITTERAE. Cuadernos sobre Cultura Escrita, n ${ }^{\circ}$ 3-4. 2003-04) y Gómez Navarro («La letra y el espíritu de la letra: notario, formulario notarial e historia. Edad Moderna» en Tiempos Modernos. Revista electrónica de Historia Moderna, V. 2, No 4. 2001). Para Albacete, las publicaciones se reducen al trabajo de García Moratalla (Los protocolos notariales de la villa de Albacete a finales del siglo XVI y comienzos del XVII (1588-1628). Estudio documental. Albacete, 1999) para finales del siglo XVI y comienzos del XVII que tan sólo trata el estudio paleográfico de los documentos emitidos por esos escribanos.

8. Bouza Álvarez, F.: Del escribano a la biblioteca, Madrid, 1992. p. 26. 
por escrito. Esta minoría se reconoce a sí misma como grupo, precisamente en función de ese instrumento que permite establecer una tradición, forjar una serie de autoridades, conservar lo adquirido y estar en disposición de transmitirlo o de no hacerlo según el mayor o menor esoterismo que sus poseedores quieran dar a ese saber. Para Gómez Navarro ${ }^{9}$ este grupo, por el desempeño de su profesión, genera conexión con su ámbito y entorno, infiltración en el complejo entramado de la realidad y posibilidad de influencia o injerencia. Extremera Extremera ${ }^{10}$ apunta que su importancia radica en su constante presencia en la vida cotidiana de la época y en su posición como eslabón entre los gobernantes y los gobernados. Y en este último aspecto Bernardo Ares ${ }^{11}$ advierte del fundamental papel de los cuerpos políticos intermedios, tanto más importantes cuanto que son los que están mas cerca de los gobernados.

Desde el punto de vista institucional, Corral García ${ }^{12}$ analiza al detalle el oficio de escribano remontando su origen al mundo antiguo como adaptación a la organización concejil de los escribas romanos. Con la decadencia del municipio durante la época visigoda desaparece, con la Curia municipal, su función autentificadora, quedando ésta en manos de los oficiales de la Casa del Rey. ${ }^{13}$

En los comienzos de la reconquista, matiza García Sainz de Baranda ${ }^{14}$, serán los religiosos los que realicen los contratos y actos de toda clase con la asistencia de testigos. A partir de este momento, los fueros comenzarán a legislar o regular las acciones de los escribanos. Para Arribas Arranz ${ }^{15}$ es el Fuero de Soria, otorgado por Alfonso VIII, el texto jurídico medieval más antiguo que realiza menciones concretas sobre el Escribano: manda que los escribanos de ciudades y villas sean puestos por el Rey o por quien él mandase. Alfonso X, de acuerdo y a petición de las Cortes, creó el cargo de escribano público y determinó la necesidad de que en cada cabeza de jurisdicción existiera un número fijo y estable de escribanos, dejando su nombramiento en manos de la Corona. Esa limitación del número de escribanos públicos implicaba la restricción, en cuanto al ejercicio profesional, de otros escribanos y notarios en el plano local. Las Partidas se convertirán en el primer texto territorial que regule las escribanías y se configura como básico para su estudio.

Sin embargo, fue con el advenimiento del Estado Moderno cuando se produjeron el mayor número de avances. El primero de ellos fue la centralización de los exámenes

9. GOMEZ NAVARRO, «La letra y el espíritu...» op. cit. p. 11.

10. Extremera Extremera, «Los escribanos de Castilla...» op. cit. p. 160.

11. Bernardo Ares, J.M.: El Poder Municipal y La Organización Política de la Sociedad. Algunas lecciones del pasado. Córdoba, 1998. p. 537.

12. Corral García, El escribano del concejo... op. cit. p. 6.

13. Gibert expone que su origen está ligado al poder de autenticación propio de la Cancillería y de la Curia del Rey, y de la Curia y del Tribunal de las Ciudades. GiBert, R.: El concejo de Madrid. Madrid, 1949. Cit. Corral García, El escribano del concejo... op. cit. p. 7.

14. García Sainz De Baranda, J.: La ciudad de Burgos y su Concejo. Burgos, 1977. p. 116. Cit. CorRAL GARCÍA, El escribano del concejo... op. cit. p. 7.

15. ARribas ARRANZ, «Los escribanos públicos...» op. cit. p. 170. 
para escribanos públicos en el Consejo Real y el control con eficacia de su número. A partir de este momento se establecieron una serie de condiciones previas para obtener el título, tales como superar un examen de suficiencia y obtener una carta real de merced firmada por, al menos, tres consejeros. ${ }^{16}$ En 1500 promulgarían una Real Pragmática por la que se prohibía arrendar las escribanías. ${ }^{17} \mathrm{Y}$ otro, sin duda el más importante para nosotros, fue el decreto por el que los escribanos debían formar y conservar los distintos protocolos o registros de escrituras notariales, dando lugar a esa valiosísima fuente documental que son los protocolos notariales.

Con el transcurso de los años, las características para el acceso a esta figura se fueron completando. Se les exigía que fuesen personas que supiesen escribir bien, libres, cristianos, de buena fama, entendidos en el arte de la escribanía, vecinos y hombres de «poridat». En 1554 se estableció la necesidad de una información previa para ser admitido a examen, y después se institucionalizó por disposición de Felipe II y Carlos II, quedando recogidas en la Nueva y la Novísima Recopilación. En 1566 se fijaría la edad mínima legal en 25 años cumplidos. Los escribanos tampoco podían tener determinados cargos, salvo que renunciasen a ejercer su oficio; primero por ley 11 de Cortes de 1596 no podían ser alcaldes, y después, por ley 16 de las Cortes de Pamplona de 1600, tampoco jurado o regidor. En 1609 se les exigió, para que pudieran ser examinados, el haber estado al menos dos años en "escritorios de secretarios, o escribanos de cámara de los Consejos y Chancillería, o audiencias, u otros cualesquier escribanos públicos que ejercen sus oficios, o en casas de abogados, o relatores o procuradores, sirviéndoles en el ministerio de sus oficios...».

En cuanto a su variedad tipológica, Extremera Extremera ${ }^{18}$ indica que su enorme diversidad se configuró como uno de los factores del gran peso que tuvieron los escribanos en la sociedad: escribanos del rey, escribanos del número, escribanos del cabildo municipal, notarios eclesiásticos, secretarios, etc.; incluso muchos de ellos compaginaban sus funciones públicas con otras de ámbito privado ejerciendo de administradores de rentas o como encargados del archivo particular de algún noble, entre otros muchos casos. Gómez Navarro ${ }^{19}$ también se hace eco de su variada denominación describiendo hasta catorce designaciones diferentes en su estudio de los escribanos cordobeses.

16. Corral García, El escribano del concejo... op. cit. p. 19.

17. Corral García, El escribano del concejo... op. cit. p. 46.

18. EXTREMERA EXTREMERA, «Los escribanos de Castilla...» op. cit. p. 161.

19. Escribano público; escribano del número; escribano público del número de esta ciudad; escribano público y mayor de rentas; escribano de su majestad y público del número; del número y de la superintendencia general de rentas reales; del rey y de registros de entradas de la puerta del puente; notario mayor del juzgado de visita eclesiástica; notario público apostólico y agente jubilado del Ilmo Sr. Dean y Cabildo de la Catedral; notario, escribano público del rey y de registros y entradas de la puerta del puente (real aduana); público del número de esta ciudad y notario del juzgado de bienes confiscados del Sto. Tribunal de la Inquisición; público y mayor de los reales servicios de millones; público y de la subdelegación de los pósitos; y escribano de rentas reales. La mayor parte de los escribanos añadían otra denominación a su específico carácter de personal «público» o de «número». GÓMEZ NAVARRO, «Un ensayo de microanálisis...» op. cit. p. 1074. 
Los numerosos títulos de nombramiento que se recogen en las actas capitulares de la villa de Albacete durante el siglo XVIII constituyen una fuente inapreciable por cuanto nos ayudan a establecer diferentes clasificaciones de escribanías. Por un lado nos encontramos a los escribanos del número, un oficio público con un gran componente administrativo, con ámbito de actuación únicamente en el municipio y su distrito, y que tiene su principal atributo en el atesoramiento de la fe pública: autorizan y otorgan legitimidad con su firma y su signo a contratos particulares y diligencias judiciales. ${ }^{20}$ También aparece el «Escribano y notario público en la nuestra corte y en todos los nuestros reinos y señoríos» o escribano de los reinos, con un mayor campo de operaciones - pues pueden ejercer en todo el reino- pero cuyas funciones están limitadas por la actuación de los primeros. Junto a ellos aparecen otros, que Cuesta Martínez ${ }^{21}$ denomina «particulares», y que en los propios títulos nos informan de una dedicación específica. En este grupo se encuentran, por ejemplo, el escribano de censos e hipote$\operatorname{cas}^{22}$ o los escribanos de millones a quienes correspondían

«todos los negocios y causas civiles, y, criminales tocantes a los servicios de cuatro millones en cada un año y dos millones por una vez que me concedió el reino y que tocaron pagar a la expresada villa de Albacete y de todos los demás servicios que después de los referidos se concedieron en cortes y tocaron a la dicha villa y de otros cualesquiera que en lugar de ellos se subrogaren, mudaren o pasaren a otras rentas o contribuciones que se eligieren y señalaren en lugar de los dichos millones aunque para su cobranza se arrienden, encabecen o administren, los dichos servicios porque todo lo que a esto tocare en la citada villa se ha de comprender en la dicha escribanía». ${ }^{23}$

Y, por último, pero para nuestro estudio, los más importantes serán los escribanos del concejo que participan de los caracteres de la escribanía pública, ya que, como norma, los escribanos de concejo habían de designarse de entre los anteriores como conditio sine qua non, y serán los responsables de las tareas administrativas y de gestión de la institución municipal: «evacuar todos los negocios de cuentas, repartimientos, veredas, ordenes circulares, testimonios saca de instrumentos y demás que ocurren».

20. MARTÍNEZ GiJÓN, «Estudios sobre el oficio...» op. cit. p. 278.

21. Cuesta Martínez, M.: Oficios públicos y sociedad. Córdoba. 1997. p. 410.

22. En el año 1768 se presentaría en el ayuntamiento una Real Pragmática por la que se prescribía el establecimiento del oficio de hipotecas en las cabezas de partido y nombraban a José Lucas Martínez para que se hiciese cargo de los libros de registro que fuesen necesarios en el ínterin que la Real Chancillería de Granada hacía señalamiento y asignación de este pueblo. (A.H.P. de Albacete. Sec. Municipios. Libro 97. Ayuntamiento de 20 de febrero de 1768). Como escribano de censo e hipotecas sería el encargado de elaborar, guardar y dar validez a todos aquellos documentos de censos o hipotecas que se realizaren en la villa. A partir de 1783 pasará a designarse este oficio en las elecciones de San Miguel, aunque de una manera efímera, pues el año 1785 será el último en el que se elijan. El salario por este trabajo quedaría estipulado por el Real Consejo en dos reales de vellón por cada escritura que se realizase.

23. A.H.P. de Albacete. Sec. Municipios. Libro 91. Ayuntamiento de 25 de junio de 1740. Título de escribano de millones en manos de Diego Gómez del Castillo. 
Estas diferencias funcionales obligaban a que los escribanos, aparte de su labor de escribas, poseyesen conocimientos administrativos e incluso jurídicos para desempeñar óptimamente sus tareas, lo que configuraba un oficio a caballo entre el mundo de la estricta burocracia y el de los servicios jurídicos especializados. Por lo tanto, coincidimos con Aranda Pérez ${ }^{24}$ en señalar que los escribanos presentan una duplicidad de funciones que, en sí misma, los caracteriza y define, en cuanto que la fe pública la desempeñan tanto en la vida jurídica privada -función escrituraria-, como en la administración municipal y en la justicia -función actuaria-, mediante su actuación en contratos, testamentos, etc., como en la vida del municipio y en la sustanciación de los pleitos civiles y criminales.

\subsection{Escribanos del número y reales}

En el estudio de las oligarquías, las escribanías del número tienen un carácter complementario, porque aunque no realizaban funciones internas en el ayuntamiento, sus miembros se encontraban estrechamente relacionados con el resto de los componentes de los grupos oligárquicos, principalmente por dos aspectos: en primer lugar por su nombramiento, pues la villa de Albacete era poseedora de una escribanía de número que repartía entre cuatro escribanos ${ }^{25}$. Y en segundo lugar, por sus vínculos con los regidores, con los que se hallaban unidos mediante relaciones familiares y clientelares que se reflejaban en los numerosos servicios que se realizaban recíprocamente.

Como hemos comentado anteriormente, el escribano del número era un oficio público de carácter eminentemente administrativo. Sus funciones se debatían entre la administración y la labor notarial de dar fe pública de todas las escrituras y demás actos que pasaran ante él. Este aspecto notarial se fijó durante el reinado de los Reyes Católicos al establecerse la obligación de la formación y conservación de todos los protocolos que pasasen ante los escribanos.

En relación a sus retribuciones, no percibían un salario fijo por el trabajo que realizaban, sino que se sustentaban mediante el cobro de derechos y aranceles aplicados sobre los documentos que realizaban. Soledad Gómez ${ }^{26}$ en este sentido señala que en cuanto a los ingresos devengados por el desarrollo de esta profesión es necesario establecer una doble distinción: Por un lado, lo que estaba legislado, y, junto a ello, la repercusión social del precepto; y, por otro, el reflejo de la norma en la realidad, es decir, en la documentación notarial. Por ejemplo, en la realización de los testamentos queda expresado claramente que el cobro del escribano por su trabajo está a su voluntad, aunque muchas veces se justifique el cobro con la ocupación de líneas escritas. En

\footnotetext{
24. ARANDA PÉREZ, Poder y poderes... op. cit. p. 135.

25. "...una escribanía de número que reparte dicha villa en cuatro escribanos quienes con el nombramiento que hace el ayuntamiento presentándole en el Real Consejo se hallan examinados a título de ella y esto no obstante anualmente en el dia 29 de septiembre de cada un año decretorio para hacer elecciones de oficios ratifica estos nombramientos para mas afianzar su propiedad...» A.H.N. Sec. Consejos. Legajo 362 .

26. Gómez NaVArRo, S., La letra y el espíritu ... op. cit. p. 4.
} 
la mayoría de las ocasiones, no se refleja si hay recaudación o no, pero lo normal es que oscile entre 1,5 y 2 reales. ${ }^{27}$ Sobre el soporte material y económico de la actividad recayeron no pocas críticas por parte de los que veían en su práctica una actividad improductiva con una intención constante de abuso. ${ }^{28}$

A través del Catastro de Ensenada ${ }^{29}$ podemos establecer una comparativa en relación con los salarios de poblaciones cercanas. Para el caso de Albacete los salarios de los escribanos oscilan entre los 800 y 1100 reales. En la respuesta a la pregunta número 32, los vecinos de la ciudad de Alcaraz contestaban que había cinco escribanos del número y uno real con una regulación de la «utilidad anual» de 150 ducados cada uno. En El Bonillo había dos maestros escribanos, uno de ellos con dos oficiales que cobraban 100 ducados al año cada uno, y el otro, con un oficial que «le regulan de utilidad 18 reales diarios». En la villa de Madrigueras no se establece con tanto detalle el número de escribanos y su categoría, sino que tan sólo señalan que había dos escribanos del número y ayuntamiento que «con lo que les da la villa de situado, sobras, testamentos, particiones y demás que actúan y se ofrece asciende la utilidad de cada uno a setecientos reales». De la misma manera, en Tarazona de la Mancha existían cuatro escribanos con una gran diferenciación en cuanto a sus retribuciones según sus competencias. Uno de ellos, José Lozano, escribano del número, particiones y ayuntamiento, percibe 1400 reales al año. Los siguientes, Julián Tendero y Juan Caballero,

27. Así lo hemos observado en nuestro estudio «Morir en Almansa: actitudes ante la muerte a principios del siglo XVIII (1700-1707)». Primer premio en la modalidad absoluta en el «II Premio de Investigación Casa Grande» Almansa. 2000. En la villa de Cáceres, Sánchez Pérez(SÁnCHEz PÉREZ, A.J.: Poder municipal y oligarquía. El Concejo cacereño en el siglo XVII. Cáceres, 1987. p. 63) señala que el escribano de censos de hipotecas de bienes raíces cobraba un real por cada escritura realizada. Gómez Navarro incide en la escasísima anotación de derechos que aparece en la documentación testamentaria, ya que sólo en una parte de la mellariense aparecen referencias a los derechos percibidos por el notario tras su firma: Quince reales de vellón en la escritura de última voluntad de Juan Rudilla Noguero; siete en la de Cristóbal Sánchez de Molina y Juan Esteban Obejero; ocho en la de Gerónimo Serena; doce «y no más» en la de Juana de la Peña; y seis, finalmente, en la de Pedro Romero (GómEZ NAVARro, «La letra y el espíritu...» op. cit. pp. 4-5.

28. Como ha señalado Miguel Ángel Extremera tanto la literatura del Siglo de Oro como el refranero popular están llenos de referencias negativas hacia el colectivo: el mismo Quevedo llega a decir en Los Sueños que los escribanos «con sus plumas, nos vuelan», donde volar es sinónimo de robar, y refranes como «De cornada de ansarón, guarde Dios mi corazón» o «Dios me libre de etcétera de escribano y de recipe de médico» son bastante ilustrativos al respecto. EXTREMERA EXTREMERA, La pluma y la vida ... op. cit. p. 191

29. Las fuentes documentales consultadas han sido: para Albacete: A.H.P. de Albacete. Sec. Municipios. Caja 734. A.H.P. de Albacete. Sec. Catastro de Ensenada, Cajas 1-6; Alcaraz: A.G.S. Dir. General de Rentas. Única contribución. Catastro del Marques de la Ensenada. Respuestas Generales de Alcaraz y agregados, Libro 325. García GOnZÁLEZ, F.: Alcaraz 1753. Según las Respuestas Generales del Catastro de Ensenada. Madrid, 1994. pp. 119-120; El Bonillo: A.H.P. de Albacete. Sec. Catastro de Ensenada. Resp. Generales de El Bonillo. Caja 54; Madrigueras: A.H.P. de Albacete. Sec. Catastro de Ensenada. Resp. Generales de Madrigueras. Caja 108; y Tarazona de la Mancha: A.H.P. de Albacete. Sec. Catastro de Ensenada. Resp. Generales de Tarazona. Caja 176. 
escribanos del número, 550 reales cada uno, y por último, Alonso García, escribano de millones, tan sólo 200 reales.

Los trámites para la designación de escribanos solían seguir un camino predeterminado. En primer lugar, era necesario superar un examen en el Consejo Real, establecido por los Reyes Católicos en $1480^{30}$, y donde se evaluaba la suficiencia, aptitud y pericia para la práctica de este oficio, con pruebas de escritura y lectura, y de la forma documental y contenidos que debían tener determinados negocios. ${ }^{31}$

La formación e instrucción de los futuros escribanos estaba sujeta a un sistema tradicional de aprendizaje, con un carácter esencialmente práctico, sobre la base de su participación durante algún tiempo en los protocolos de otros escribanos y con la lectura de manuales y formularios profesionales.

Existían una serie de incompatibilidades por las que se prohibía a un personaje el ejercer como escribano. No podían ser regidores, clérigos, recaudadores, arrendadores ni tener ya una escribanía. También se les prohibía vivir con prelado o caballero, pública o secretamente, admitir depósitos de dinero, intervenir en la administración de justicia, participar en la recaudación, administración y arriendo de las rentas reales. Y también sería incompatible con el ejercicio de oficios viles. Una vez realizado el examen se expedía una carta real de merced firmada por, al menos, tres consejeros que el escribano debía presentar ante el consistorio para poder jurar y tomar posesión de su oficio. ${ }^{32}$

El derecho de nombramiento de los escribanos recaía en el Rey. Sin embargo, al igual que sucede con la mayoría de los oficios - a excepción de los jurisdiccionaleseste derecho de nombramiento de los escribanos por parte de la Corona estará sujeto a la venta de oficios y al posterior proceso de patrimonialización por parte, tanto de particulares, como de la propia institución municipal.

El tema de la enajenación, venta o venalidad de oficios ${ }^{33}$ ha sido uno de los aspectos más estudiados de nuestro régimen municipal, tanto desde el punto de vista institucional -por los historiadores del derecho-, como desde el de las oligarquías. ${ }^{34}$ Tomás y

30. Nueva Recopilación. IV, 25, 2; Novísima Recopilación. VII, 15, 3 y X, 23, 7.

31. Pardo Rodríguez, M.I.: «Exámenes para escribano público en Carmona de 1501 y 1502», en Historia, Instituciones, Documentos. N ${ }^{\circ} 20,1993$. p. 308.

32. «...tenga a dicho José Lucas Martínez por tal escribano real y se le guarde en todas las honras y franquezas que deben ser guardadas habiendo entrado en este ayuntamiento por dicho alcalde mayor se le recibió juramento el que hizo en la forma acostumbrada de defender la pureza y limpieza de María santísima nuestra señora y cumplir con la obligación de su oficio». A.H.P. de Albacete. Sec. Municipios. Libro 88. Ayuntamiento de 22 de mayo de 1728.

33. Este tema era ya tratado en la propia mentalidad de la época, como se observa en la literatura satírica en obras de Quevedo, Lope de Vega o el mismísimo Cervantes en El Quijote, donde los personajes ponen sus máximas ilusiones y ambiciones en la consecución por compra o donación de un oficio con el que vivir cómodamente, ya sea una regiduría, una arrendaduría de alcabalas o similar. MERCHÁN FERNÁNDEZ, Gobierno municipal y administración local... op. cit. pp. 122-123.

34. Véanse los trabajos de Beneyto Pérez, J. y Fraga Iribarne, M.: «La enajenación de oficios públicos en su perspectiva histórica y sociológica», en Centenario de la Ley del Notariado, Madrid, 1964; 
Valiente ${ }^{35}$ señala que en Castilla comenzó el tráfico privado de oficios públicos mucho antes de que en él interviniera la Hacienda real con ánimo de obtener provecho del mismo. Fue Felipe II quien autorizó la realización de operaciones de ventas de oficio públicos planeadas desde el Consejo de Hacienda y realizadas con la finalidad de obtener con ellas el máximo y más inmediato beneficio. ${ }^{36}$ Este mismo autor estructura los oficios vendibles en tres grupos: los oficios «de pluma», sobre todo escribanías; los oficios de poder, entre los que destacaban los alferazgos mayores, regidurías, juradurías, alguacilazgos, etc; y, los oficios de dineros, depositarios, receptores, contadores, fieles, entre otros. ${ }^{37}$

Los compradores de los «oficios de pluma», por lo general, pertenecían al pueblo llano y como para desempeñarlos se debían poseer ciertas capacidades profesionales, muchos de los candidatos se debían conformar con poseerlo en propiedad, sin llegar a ejercerlos. Pero en todos ellos, serían las gentes adineradas las que más oficios comprasen, y de los tres tipos, como forma de ascender socialmente.

En la pregunta número 28 del catastro de Ensenada se ofrece un listado de empleos y alhajas enajenados de la Real Corona donde se señala, que en la villa de Albacete existía «una escribanía de número que ejercita Juan Martínez Arenas propia de D. Pedro Navarro de Cantos y otra de Millones que usa Diego Gómez del Castillo propia

CuARtas Rivero, M.: «La venta de oficios públicos en el siglo XVI», en Actas del IV Symposium de Historia de la Administración. Madrid, 1983. pp. 225-260; DOMÍngueZ OrTIZ, A.: «La venta de cargos y oficios públicos en Castilla y sus consecuencias económicas y sociales», en Anuario de Historia Económica y social. T. III. (1975). pp. 105-137; GonZÁLEZ ALONSO, B.: «Sociedad urbana y gobierno municipal en Castilla (1450-1600), en Sobre el Estado y la Administración en la Corona de Castilla en el Antiguo Régimen. Madrid, 1981. pp. 57-83; HeRnÁndeZ BENITEZ, M.: «Y después de las ventas de oficios, ¿qué? (Transmisiones privadas de regimientos en el Madrid moderno, 1606-1808)», en Anuario de Historia del Derecho Español, LXV. 1995; TOMÁs Y VALIENTE, F.: «Las ventas de oficios de regidores y la formación de las oligarquías urbanas en Castilla», en Actas de las I Jornadas de Metodología Aplicada de las Ciencias Históricas, vol. III. Santiago de Compostela, 1976. pp. 551-568; Id.: «Ventas de oficios públicos en Castilla durante los siglos XVII y XVIII», en Gobierno e instituciones en la España del Antiguo Régimen. Madrid, 1982. pp. 151-178; Id.: «Origen bajomedieval de la patrimonialización y enajenación de oficios públicos en Castilla», en Actas del I Symposium de Historia de la Administración. Madrid, 1970. pp. 125-159; Id.: La venta de oficios en Indias. Madrid, 1972; Id.: «Dos casos de ventas de oficios en Castilla», en Homenaje al Dr. D. Juan Reglá Campistol. Valencia, 1975. pp. 333-343; Id.: «Opiniones de algunos juristas clásicos españoles sobre la venta de oficios públicos», en Estudios en Homenaje al profesor Corts Grau. Valencia, 1975, pp. 625-649; TORRAS I RIBÉ, J.M.: «La venta de oficios municipales en Cataluña (1739-41), una operación especulativa del Gobierno de Felipe V», en Actas del IV Symposium de Historia de la Administración. Madrid, 1983. pp. 725-48.

35. Tomas y VALIENTE, Gobierno e instituciones,... op. cit. pp. 163-165.

36. Las razones por las que la Corona enajenaba, podían resumirse en tres: una, puramente económica, pues la Hacienda había encontrado un sistema para obtener ingresos extras con los que sanear la economía: otra, política, ya que mediante estos favores se aseguraba el extender sus redes clientelares en todos los municipios; y, la última, social, porque existía un gran sector social ávido de ascender en la escala socioestamental, y que veía en los oficios públicos una muy buena ocasión para hacerlo. DOMíNGUEZ ORTIZ, «Venta de cargos y oficios públicos...» op. cit. p. 146; ARANDA PÉREZ, Poder y poderes... op. cit. p. 214.

37. TOMAS Y VALIENTE, «Ventas de oficios públicos en Castilla...». op. cit. pp. 158-162. 
de Pedro Orea». ${ }^{38}$ Del mismo modo, y aunque en dicha respuesta no se contempla, la villa también era poseedora de otra escribanía del número.

Estos oficios patrimonializados estaban en manos de personajes de clase media que, curiosamente, siguieron trayectorias parecidas. El primer título de escribano del número estaba en manos de Pedro Navarro de Cantos, hijo de Bartolomé Navarro de Toledo, que ejerció como escribano a principios de siglo y que pronto emparentaría con la poderosa familia de los Cantos. En el año $1754^{39}$ el Sr. Pedro Navarro y su familia obtenían una de las escribanías del número de la villa en lugar de su difunto hermano Francisco Navarro de Cantos. Un oficio que se hallaba dentro del vínculo que fundó Francisco Munera Spuche y Carrasco. Este oficio tenía la preeminencia de poder nombrar tenientes, que serán, en definitiva, los que verdaderamente lo ejerzan durante la segunda mitad del siglo XVIII. La familia de los Navarro Cantos se irá consolidando durante este tiempo llegando también a ejercer dos oficios de regidores. Uno en manos del propio Pedro Navarro, y otro en las de su hermano José.

Por otro lado, la escribanía de millones era propiedad de Pedro Orea, hijo de otro escribano de principios de siglo, Antonio Orea, también de la clase media, quien poseía este oficio de la escribanía de millones por juro de heredad y con la facultad de poder nombrar tenientes. Sus buenas relaciones dentro del consistorio se observan en su nombramiento como escribano del número desde el año 1720 hasta el 1767 y en sus reiteradas actuaciones como escribano de ayuntamiento también entre esos años. Junto a este oficio poseían un título de regidor -que en el momento de realizarse el Catastro estaba en manos de Gil Fernández Benítez-, otro de fiel de carnicerías y también uno de contador de cuentas y particiones.

La escribanía del número propiedad de la villa se debía repartir entre cuatro escribanos, cuya designación se realizaba anualmente el día de San Miguel, ratificando de esta manera los nombramientos para afianzar la propiedad. Este nombramiento sólo se podía realizar cuando se producía una vacante, por abandono o defunción, por lo que se les impedía a los capitulares que fuesen eligiendo escribanos conforme a su antojo, y convertía el acceso a este oficio en una tarea nada fácil. Tras la notificación en el ayuntamiento de la vacante comenzaba el proceso para suplir su hueco. El primer paso consistía en crear una comisión formada por el escribano del ayuntamiento y varios regidores para realizar el inventario de todos los documentos que se encontraban en su protocolo. Posteriormente se procedía a la designación de un nuevo escribano, bien entre los públicos titulados o entre los personajes capacitados profesionalmente para su ejercicio, que residían en la villa y que, sin tener nombramiento real, podían ser nombrados por la villa y finalmente el aspirante designado debía presentarse ante el Real Consejo, donde se les examinaba y se expedía el título oficial. ${ }^{40}$

38. A.G.S. Dirección General de Rentas. Única contribución. Catastro del Marques de la Ensenada. Respuestas Generales de la villa de Albacete, Libro 463.

39. A.H.P. de Albacete. Sección Municipios. Libro 94. Ayuntamiento de 24 de julio de 1754.

40. «D. Miguel Rubin de Noriega So. de Cámara del Rey nuestro señor de los que residen en el Consejo certifico que habiéndose presentado ante los ss. del Pedro Gómez de la Cuesta con un nombramiento 
Estos escribanos nombrados por la villa debían pagar, como derecho por ejercer este cargo, una pensión o arrendamiento al cabildo que estaba estipulada en 250 reales al año. Precisamente, el pago de esta pensión fue utilizado por algún personaje en momentos determinados para facilitar su acceso. En las elecciones de oficios del año $1706^{41}$ quedó vacante una de las escribanías por fallecimiento de García Ranjel, para cuya sustitución se presentaron tres candidaturas: Domingo José Martínez, que había "practicado muchos años a así en el oficio de presente escribano como en los demás del número de esta villa», Diego Fernández y Fernando Jiménez de la Cárcel quien, a pesar de haber estado ocupado en la "asignación de la iglesia» sin haber ejecutado el oficio de escribano, resultaría elegido por haber acompañado su petición con el pago de 300 reales anuales, 50 más de lo que se venía pagando.

Junto a estos oficios numerarios aparecen otros denominados «Escribanos y notarios de los reinos», cuyo título de nombramiento - que presentaban ante el concejo- les capacitaba para poder ejercer como notarios y escribanos públicos, por toda su vida, tanto en la Corte como en cualquier otro territorio de realengo y señorío. En cuanto a sus funciones, junto a los escribanos del número, desarrollaban una actividad profesional distinta aunque complementaria. El de los reinos, si bien estaba autorizado por la ley y por sus títulos para dar fe de todos los autos extrajudiciales y de los judiciales si fuesen elegidos por los jueces, no podía actuar con autoridad propia, sino por encargo o consentimiento de los numerarios en autos radicados en sus oficios, bien sea trabando sus ejecuciones, bien practicando apremios o bien realizando sus notificaciones. ${ }^{42}$

Como a tales escribanos reales, se les debía guardar todas las «honras, gracias, mercedes, franquezas, libertades, exenciones, preeminencias, prerrogativas e inmunidades y todas las otras cosas que son y debe ser guardadas a cada uno de los otros nuestros escribanos y notarios públicos de la nuestra corte reinos y señoríos». Asimismo se les otorgaba un signo que debían utilizar para firmar en todos los documentos que realizasen como símbolo de su oficio.

Durante el siglo XVIII una buena parte de los escribanos de la villa de Albacete conseguirían su título de «Escribano y notario público» con anterioridad a servir alguna escribanía numeraria o del concejo. De los 19 escribanos, 9 de ellos obtendrán un título oficial por parte de la Corona en el que se les nombrará como escribanos y notarios de Su Majestad. El resto permanecerán en los estudios de estos escribanos o de los

de escribano del numero de la villa de Albacete hecho en el por la justicia y regimiento de la dicha villa a quien hoy toca y pertenece el dicho nombramiento el que hicieron en el susodicho en lugar y por dejación de Mateo López Carbonel los dichos señores del consejo le examinaron y habiéndole hallado hábil y suficiente le aprobaron y dieron licencia y facultad para usar y ejercer el dicho oficio de escribano del numero de la dicha villa de Albacete en conformidad del dicho nombramiento de que se declaró haber pagado el derecho de la media annata y para que conste de pedimento del dicho Pedro Gómez de la Cuesta y por mandato de los dichos señores del consejo doy esta certificación en Madrid a veintiocho días del mes de junio de mil setecientos y uno». A.H.P. de Albacete. Sec. Municipios. Libro 85. Ayuntamiento de 12 de julio de 1701.

41. A.H.P. de Albacete. Sec. Municipios. Libro 86.

42. Cuesta Martínez, Oficios públicos y sociedad... op. cit. p. 420. 
de ayuntamiento y número como aprendices y oficiales ${ }^{43}$ o encargados en tareas particulares, hasta dar el salto definitivo a una de las escribanías numerarias, bien por designación del ayuntamiento, o bien como tenientes del oficio de los «Navarro Cantos».

Así, por ejemplo, a mediados de este siglo, cuando se cruzaron diferentes informes al Consejo solicitando la reducción de la alcaldía mayor de Albacete a corregimiento, Miguel de Tafalla, presbítero y teniente de Vicario de esta villa, aparte de exponer el crecimiento que la misma había mostrado en los últimos años, informaba que se hallaban para el despacho del juzgado "cinco escribanos del numero y tres reales». Esos cinco escribanos del número se constituyeron en un grupo definido: cuatro de ellos serían los nombrados por el ayuntamiento y otro por la escribanía de los Navarro. Por otro lado, el grupo de los escribanos reales iría variando conforme fuesen obteniendo su título.

Para finalizar este apartado no queremos dejar de hacer mención a los derechos y obligaciones. El estudio de Corral García ${ }^{44}$ en su capítulo II establece claramente cuáles eran los derechos y deberes de estos escribanos. Entre los derechos se encuentran los económicos, derivados del cobro de salarios o aranceles, los no económicos, de entre los que podemos destacar claramente las honras, gracias, mercedes, franquezas, libertades, exenciones, preeminencias, prerrogativas e inmunidades y todas las otras cosas que se les debían guardar, y por último, el derecho a asociarse mediante colegios o cofradías que funcionarán, sobre todo, en las grandes ciudades como Toledo ${ }^{45}$, Córdoba ${ }^{46}$ o Ávila ${ }^{47}$.

Entre sus obligaciones estaba, en primer lugar, el deber de servir personalmente los oficios sin poder darlos en arrendamiento. Un deber que en la práctica no se llegaría a cumplir, pues muchos de los escribanos tenían sus oficiales y aprendices que se encargaban de la confección material de los documentos, y otros tantos arrendaban este oficio perpetuado para obtener beneficios. Otra de las obligaciones era la de "poridat» o deber de sigilo. Debían de actuar con discreción y reserva, guardando en secreto todo lo que ante ellos se tratara. Y, por último, la fidelidad y lealtad. Debían representar con fidelidad todo lo escrito, tanto en los testimonios directos como en los traslados, y asimismo, tenían el deber de lealtad al Rey, que era quien les había nombrado o confirmado. Sin embargo, los abusos y comportamientos delictivos en ocasiones fueron frecuentes, lo que ayudó a fortalecer la imagen de mala reputación que afectaría todo este colectivo profesional. En 1780, por ejemplo, el corregidor de la villa José Duran y Flores atacaba al escribano José Lucas Martínez exponiendo que era

\footnotetext{
43. En el Libro de Vecindario del Catastro de Ensenada aparecen Francisco Andujar de 25 años, casado y con un hijo, de profesión oficial de escribano, y su personal 360 reales anuales, y, Gregorio Martínez Arenas, también de 25 años, casado y con dos hijos, con un personal de 220 reales anuales. A.H.P. de Albacete. Sec. Municipios. Caja 734

44. Corral García, El escribano del concejo... op. cit. pp. 39-54.

45. Aranda PÉREZ, Poder y poderes... op. cit. pp. 136-138.

46. EXTREMERA EXTREMERA, «Los escribanos de Castilla...» op. cit. pp. 168-170.

47. Corral García, El escribano del concejo... op. cit. p. 44.
} 
«...escribano de cabildo mucho a y todo lo despacha sin titulo ni oficio tan apegado a los regidores que incurriría en la mayor torpeza por llevar adelante sus ideas. Este les compone las cuentas tapando en ellas las cantidades que faltan agrega gastos suponiéndolos hechos en alivio de los montes cuando es cierto que de veinte años a esta parte no se ha gastado ni un real y solo se ha tirado a destruirlos con escándalo del común apoyando lo que dice con falsos certificados y haciendo que los guardas firmen declaraciones que forma en que aseguran haber impedido aquellas cantidades en los fines que se supone y si así no lo hicieran serian depuestos y castigados». ${ }^{48}$

A otro, Martín del Peral, algunos capitulares, contrarios a su bandería, lo calificaban como un «agente descubierto» contra la villa en el pleito que ésta estaba siguiendo contra los señores de Pozo Rubio. Y es más, intentarían expulsarle de las escribanías numerarias propias de la villa, suplicando al Consejo que diese por vaco este oficio por la «ingratitud» que había demostrado.

Como ha señalado Aranda Pérez ${ }^{49}$, otra de las obligaciones resultaba de la participación de los escribanos en la administración de justicia, que les obligaba a evitar y a castigar toda parcialidad posible en sus actuaciones: ser abogados, procuradores o solicitadores de parte; actuar en causas de sus familiares directos, ya fueran reos o abogados, etc.; no podían autorizar escritura en favor de algún familiar directo; recibir dones o dádivas de las partes; admitir los depósitos judiciales originados por las causas que ante ellos pendieren; habitar en las casas de personas poderosas del concejo; llevar salarios de instituciones eclesiásticas (iglesias o monasterios) y menos aún de personas particulares siendo escribanos del concejo. Relacionado con estas ocupaciones a partir de $1775^{50}$ los escribanos ejercerían como tasadores de pleitos cuya finalidad era la de fijar y determinar el precio de los pleitos que se llevasen a cabo en la audiencia judicial. Este nombramiento debió implantarse con la llegada del corregidor propio para la villa, pasando a ser elegido en las elecciones de oficios del día de San Miguel como uno más de los propios de la villa. Por lo general, y hasta finales de siglo, recaerá siempre en los escribanos del ayuntamiento, compartiendo de esta manera ambas atribuciones.

\subsection{Escribanos de ayuntamiento}

De entre todos los componentes de este grupo profesional el más importante en la esfera municipal era el escribano de ayuntamiento o del concejo, que la villa de Albacete tenía derecho a nombrar y que solía hacerlo de entre los escribanos del número. ${ }^{51}$

48. A.H.N. Sec. Consejos. Legajo 876.

49. ARANDA PÉReZ, Poder y poderes... op. cit. pp. 135-136.

50. A.H.P. de Albacete. Sec. Municipios. Caja 243 B. Ayuntamiento de 1 de enero de 1775.

51. Tradicionalmente se elegían cada año dos escribanos de ayuntamiento, pero en el año 1568 sería enajenada una de estas escribanías del concejo, dejando el otro oficio para que se eligiese por votación anual. El oficio enajenado se consumiría definitivamente, no sin problemas, en 1624 por mandamiento de Baltasar Gilimón de la Mota, comisionado real para el consumo de oficios. CORCOLES JiMÉNEZ, M.P.: La villa de Albacete en la primera mitad del siglo XVII. Estructura y funcionamiento de la administración municipal. Albacete, 2008. pp. 97-99. 
Uno de los principales problemas que nos encontramos a la hora de abordar el estudio de los escribanos del ayuntamiento o del concejo es, junto a la falta de interés historiográfico, el escaso apoyo documental que se refleja en las actas capitulares hacia esta figura. Al contrario de lo que ocurre con el resto de oficiales del concejo, los escribanos no se presentan enumerados en el encabezamiento de cada acta, sino que la única mención de su asistencia será su rúbrica, que aparece al final, detrás de todas las firmas de los asistentes, bajo el epígrafe de «ante mi» o «ante nos» según fuesen necesarias una o dos personas para el correcto desenvolvimiento institucional.

Pero este desplazamiento hacia un segundo plano al que quedan relegados los escribanos en la actividad documental administrativa, no es reflejo de su importancia dentro del ayuntamiento. Su presencia en los ayuntamientos era obligada, pues era el encargado de preparar las sesiones, levantar acta de todo lo que se discutiese y acordase por mayoría ${ }^{52}$, llevar los libros de actas correctamente, hacerse cargo de una de las llaves del archivo, hacer las copias necesarias de los documentos municipales, y dar testimonio de validez de aquello que se trataba. ${ }^{53}$ Era un miembro más del concejo, que aunque no formaba parte política del ayuntamiento - pues no tenía voto en las reuniones y su actuación dependía siempre del mandato del justicia mayor y los regidores-, constituye una pieza inexcusable en la vida municipal del Antiguo Régimen. Con el paso del tiempo, serán el origen de otras figuras importantes en la administración como son los secretarios judiciales y municipales.

No sabemos con exactitud la fecha en la que la villa de Albacete obtuvo el privilegio de nombrar sus propios escribanos de ayuntamiento, aunque sí tenemos aproximaciones. En las elecciones de oficios de $1701^{54}$ el recién llegado al corregimiento de Chinchilla, Jerónimo Goñi, actuando como justicia mayor en esa reunión solicitó a los capitulares que la villa exhibiese el título o privilegio que tenía para hacer nombramiento de escribano de su ayuntamiento. A lo que la villa contestó mostrando diferentes libros capitulares «y entre ellos uno en el que están los acuerdos del año de mil quinientos y noventa» en el que ya constaba como la villa tenía costumbre de hacer nombramiento de dicho escribano.

Por lo tanto, los escribanos del concejo en la villa de Albacete se elegían por los capitulares el día señalado para la elección de oficios, alejándose de la enajenación que se produce en otros lugares ${ }^{55}$. Por lo general, se designaban de entre los escribanos

52. Debe tomar nota, no sólo de todo aquello que se acuerde, sino también de todos los temas del orden del día y, en realidad, de todo sobre lo que se discuta. Sólo podrá levantar acta de lo que se apruebe por mayoría, pero debe tomar nota de las protestas hechas a los acuerdos, por si fuera necesario dar testimonio. HiJAnO PÉREZ, A.: El pequeño poder: el municipio en la Corona de Castilla, siglos XV al XIX. Madrid, 1992. p. 137-38.

53. SÁNCHEZ PÉREZ, Poder municipal... op. cit. p. 63.

54. A.H.P. de Albacete. Sec. Municipios. Libro 85.

55. Marina Barba señala que en la mayoría de los ayuntamientos las personas que ocupaban las escribanías eran los propietarios de empleos que habían comprado o heredado. MARINA BARBA, J.: Poder municipal y reforma en Granada durante el siglo XVIII. Granada, 1992. p. 110. 
numerarios y reales. Como tales tenían los mismos deberes que aquellos, aunque por su condición de dependencia del concejo gozaban de unas atribuciones específicas relacionadas con todo lo que se tratase en el ayuntamiento. Su condición de dar fe se extendía a todos aquellos negocios en los que participase el municipio como institución $\mathrm{y}$ en lo que se requiriese la presencia de sus atribuciones: «evacuan todos los negocios de cuentas, repartimientos, veredas, ordenes circulares, testimonios saca de instrumentos y demás que ocurre». ${ }^{56}$ Por lo que tendrá una gran importancia en el desarrollo de las tareas administrativas y de gestión municipal.

Para López Díaz ${ }^{57}$ eran obligaciones de la persona que ejercía este cargo, entre otras, acudir con puntualidad a las sesiones de consistorio y guardar secreto de ellas, asentando lo acordado en un libro, tener otros dos libros donde se registrasen en uno las penas de cámara y en el otro las audiencias de los alcaldes, etc.

Entre sus derechos, al igual que los escribanos que trabajaban para la administración central, se le establecía un salario fijo que se les debía satisfacer de los caudales de propios del ayuntamiento. ${ }^{58}$ Legalmente no podían percibir ningún derecho o arancel añadido por la participación en este oficio, como señala Castillo de Bobadilla: «Por su ocupación los escribanos podrán recibir un moderado salario de los propios pero no cobrarán derechos por pregones ni remates ni escrituras ni procesos, que por su oficio están obligados a ello». ${ }^{59}$ Sin embargo, los pagos por estos conceptos serán una constante durante todo el siglo. Por ejemplo, en la administración de los pósitos, según la Real Instrucción de 30 de mayo de 1753 se establecía que el escribano del pósito - que era uno de los del ayuntamiento- debía cobrar por «vía de gratificación y no de salario» un maravedí por cada fanega de las que se reintegrasen. ${ }^{60}$ Además, en numerosas ocasiones, al ser elegidos también como escribanos del número del oficio que pertenecía a la villa se les perdonaría la «pensión» que debían pagar. Y, entre otros, se les administraba una serie de dietas o ayudas, como por ejemplo, por "asistencia al sitio de los Llanos la villa con su alcalde mayor comisarios, escribano y ministros en el tiempo de los tres días de feria». ${ }^{61}$

56. A.H.N. Sec. Consejos. Legajo 1108.

57. López DíAZ, M.: Oficios municipales de Santiago a mediados del siglo XVIII. La Coruña, 1991. p. 135.

58. Sobre este aspecto resulta interesante el trabajo dirigido por Alvar Ezquerra sobre los escribanos del concejo de Madrid a finales del siglo XVI en el que se recoge al detalle un cuadro resumen del arancel de un escribano de ayuntamiento por tipo de acto o escritura aprobado por los Reyes Católicos y ampliado posteriormente en la Nueva Recopilación. Alvar EzQuerra, A., Garcia Guerra, E., Prieto Palomo, T. et al. «Los Escribanos del Concejo de Madrid (1561-1598)» Cuad. Hist. Esp. [online]. ene./dic. 2005, vol.79, p.167-201.

59. Castillo De Bovadilla, J.: Politica para Corregidores y Señores de Vasallos..., (2 volúmenes). Madrid, 1597. (Facs. de la edición de 1704: Instituto de Estudios de la Administración Local. Madrid, 1978). p. 50.

60. Losa Serrano, P. y Cózar GutiÉRrez, R.: La conflictividad social en la Mancha Oriental. Los motines de Tobarra y Liétor. Toledo, 2003; Id: «Los pósitos municipales. El ejemplo de Tobarra (1753-1764)», en la VII ${ }^{a}$ Reunión Científica de la Fundación Española de Historia Moderna. Ciudad Real, 2002.

61. A.H.N. Sec. Consejos. Legajo 284. Exp. 4. 
A partir de 1759, los dos escribanos del ayuntamiento de Albacete verán aumentado su salario a 3300 reales por mitad. ${ }^{62} \mathrm{Si}$ los comparamos con lo estudiado en los municipios cercanos que analizamos en el apartado de los escribanos del número, podemos observar ciertas semejanzas con poblaciones como El Bonillo ${ }^{63}$ (1100 rs.) o Tarazona de La Mancha ${ }^{64}$ (1400 rs.) y se aleja de los 700 reales de la villa de Madrigueras ${ }^{65}$ y los 200 de la ciudad de Alcaraz ${ }^{66}$. A nivel nacional, tenemos otras cifras comparativas que quedan muy lejos de estas cantidades, como son los 2200 reales que cobraban los escribanos en Santiago de Compostela ${ }^{67}$ o los 4500 rs. de Granada ${ }^{68}$.

En muchas ocasiones, como era muy corriente que los propios escribanos del concejo fuesen también designados como escribanos del número de la villa, se recogía en su nombramiento que no se les cobrase la pensión a aquellos que simultaneaban ambos oficios. Este es el caso de Fernando Jiménez a quién se lo recordarían en las elecciones de oficios del año $1707^{69}$. Pero éste no sería el único asunto relacionado con el salario que mantuvieron los escribanos dentro del concejo. En $1708^{70} \mathrm{el} \mathrm{Sr}$. Jiménez solicitaba que se le pagase los «derechos y emolumentos» de los trabajos que había realizado hasta la fecha. Estos retrasos en los pagos del salario de los escribanos eran muy frecuentes durante todo el período estudiado y dio origen a numerosas peticiones de los interesados en las reuniones capitulares.

Otra de las quejas frecuentes era motivada por el pago del papel sellado. En 1637 bajo el reinado de Felipe IV, se instauró una tasa sobre la documentación oficial y privada, con el fin de aumentar los ingresos de la Corona. Esta tasa consistía en la instauración del uso de sellos en todos los documentos generados por los escribanos, como contratos, autos, escrituras, provisiones y otros instrumentos. Para evitar las posibles falsificaciones, los sellos tenían una validez de dos años, al cabo de los cuales debían expedirse otros nuevos. Con el fin de aprovechar el papel que no se utilizara, durante el bienio establecido por los sellos, se autorizaba su resello. El papel sellado era vendido

62. «Acordaron que en atención al grave trabajo que tiene la escribanía del ayuntamiento en todos sus negocios de asistencia a él y las demás dependencias que diariamente ocurren del real servicio para evacuar de sus ordenes por veredas y demás perteneciente a su gobierno económico del ayuntamiento, padrones y cuentas; señalaban y señalan que todo este dicho año contado desde este día hasta otro tal del siguiente trescientos ducados a ambos trabajándolo y atendiendo por ahora a las cortedades de esta villa y sus empeños. Y que en adelante se les tendrá presentes». A.H.P. de Albacete. Sec. Municipios. Libro 95. Ayuntamiento de 29 de septiembre de 1759.

63. A.H.P. de Albacete. Sec. Catastro de Ensenada. Respuestas Generales de la villa de El Bonillo. Caja 54. 64. A.H.P. de Albacete. Sec. Catastro de Ensenada. Resp. Generales de la villa de Tarazona. Caja 176.

65. A.H.P. de Albacete. Sec. Catastro de Ensenada. Resp. Generales de la villa de Madrigueras. Caja 108.

66. A.G.S. Dirección General de Rentas. Única contribución. Catastro del Marques de la Ensenada. Respuestas Generales de la ciudad de Alcaraz y agregados, Libro 325. GARCíA GonZÁLEZ, F.: Alcaraz 1753. Según las Respuestas Generales del Catastro de Ensenada. Madrid, 1994.

67. LÓPEZ DÍAZ, Oficios municipales... op. cit. p. 166.

68. MARINA BARBA, Poder municipal y reforma... op. cit. p. 110.

69. A.H.P. de Albacete. Sec. Municipios. Libro 86. Ayuntamiento de 29 de septiembre de 1707.

70. A.H.P. de Albacete. Sec. Municipios. Libro 86. Ayuntamiento de 11 de junio de 1708. 
y distribuido por oficiales reales que se encontraban en la ciudad de Chinchilla, por lo que la villa debía nombrar cada año un receptor del papel sellado que se encargarse de traerlo y suministrárselo a los escribanos.

Pues bien, las actas capitulares también se realizaban sobre este tipo de papel, por lo que su compra o el pago de este derecho recaía en primer lugar en los escribanos del concejo, lo que motivaba diferentes peticiones o quejas ante el consistorio para que se les devolviesen estos gastos que en realidad eran propios del municipio. ${ }^{71}$

Al igual que los regidores, posiblemente no fuesen estos «derechos» los que más incentivasen a los escribanos, sino las ventajas que el cargo les ofrecía. Unas ventajas en cuanto a exenciones fiscales, militares y penales y su participación como un miembro más del concejo -aunque sin voto- lo que le haría relacionarse con los principales actores de la política municipal y situarse en una posición intermedia. Sin embargo, debido a la conflictividad entre grupos que se da durante todo el siglo XVIII, esa tensión que se refleja incluso en las mismas elecciones, les hará decantarse por el bando que les colocó en ese puesto.

De todos modos su influencia en el consistorio se demuestra en las peticiones que en muchas ocasiones se representan ante el concejo para intereses personales, y que les llevarán a ir acumulando bienes, prestigio y poder. En $1745^{72}$, por ejemplo, Pedro de Orea, escribano de ayuntamiento solicitaba licencia para que se le asignasen, mediante arrendamiento, 300 almudes de tierras en los heredamientos de Meledriz y Bacarcia, a lo que los capitulares presentes no pondrían ninguna pega. Curiosamente en $1760^{73}$ solicitaría al concejo que se les borrasen las deudas que había contraído con la villa por estas tierras de labor, debido a los muchos y buenos trabajos que había realizado para la villa, a lo que la villa volvió a acceder. Con el tiempo el Sr. Orea llegaría a poseer, además de numerosos bienes, un título de regidor, otro de escribano de millones, otro de fiel de tercias y otro de contador, todos ellos arrendados a terceras personas.

\section{PERFIL SOCIAL DE LOS ESCRIBANOS}

Para profundizar en los mecanismos de influencia y relaciones con el poder nos planteamos definir socialmente a los actores que participaban de manera activa en este grupo profesional. Para ello vamos a analizar distintas dimensiones como sus parámetros socio-económicos y su pertenencia a grupos y redes de relación.

\subsection{Parámetros socio-económicos}

Los individuos que actuaron como escribanos en la villa de Albacete pertenecen, en su mayoría, a la clase media, aunque con diferencias tanto en sus calidades como, sobre todo, en sus niveles de renta. Su origen social son personas humildes que se profesionalizan y pretenden mejorar social y económicamente, pertenecientes a ese no del

71. A.H.P. de Albacete. Sec. Municipios Libro 86. Ayuntamiento de 8 de octubre de 1709.

72. A.H.P. de Albacete. Sec. Municipios Libro 92. Ayuntamiento de 15 de octubre de 1745.

73. A.H.P. de Albacete. Sec. Municipios Libro 95. Ayuntamiento de 17 de septiembre de 1760. 
todo definido «estamento intermedio» del que habló J. A. Maravall ${ }^{74}$ y que abarcaba un amplio espectro de situaciones en el que se incluían desde escribanos a quienes la élite trataba casi como a iguales a otros de muy bajo linaje y diversas procedencias que se incorporaban a la profesión sin necesidad de tradición familiar o ascendientes vinculados a la misma. ${ }^{75}$

El Catastro de Ensenada concede un valor por el personal de estos oficios de 880 rs. por la escribanía del número y 1200 rs. por la de ayuntamiento. Sin embargo, a la hora de analizar en conjunto los ingresos de estos escribanos observamos distintos valores según las competencias y características de los empleos que se estuviesen ejerciendo. Así aparece José Lucas Martínez que cobra 1350 rs. que se distribuyen en 250 por la escribanía del número y 1100 por la de ayuntamiento; mientras que por otro lado, el que menos cobra será Gregorio Martínez Arenas ${ }^{76}$ con 220 rs., que se asemeja a lo reseñado para cualquier jornalero. Algunos completarían sus ingresos con el desempeño de otras ocupaciones. El escribano al que se le reconocen unos ingresos anuales más altos será Diego Gómez del Castillo con 1830 rs. anuales y que se distribuyen en 500 rs. por el oficio de escribano de millones, 1100 rs. por interventor del correo y 230 rs. como administrador del beneficio de San Fulgencio.

Observemos dos casos que nos ayudarán a analizar los ingresos y el patrimonio que iban acaparando los personajes de este grupo. Para ello, hemos elegido a José Lucas Martínez por ser el escribano del número más antiguo (72 años) del que se recogen datos en el Catastro de Ensenada. Y por otro, Francisco Javier de Vera, el más joven (36), escribano real y de ayuntamiento. El primero de ellos, junto a los 1200 rs. que obtenía de beneficio anual como escribano de ayuntamiento, contaba con ocho fincas urbanas: cuatro casas completas, una en la calle Marcilla, otra en la calle de la Botica vieja, otra pequeña en el alto de la villa, y la última, en la calle de San Antón; una casa horno en la calle mayor; la mitad de otra casa en la misma calle y dos cuartos de casa, ambas en la calle Padre Romano, lo que le suponía unos ingresos de 840 reales anuales. Además, también poseía 74,97 Ha. en fincas rústicas, repartidas entre huertas, viñas, labradío de secano, azafranares, y su mayor parte, en el heredamiento de Casa Molina con 300 almudes en diez piezas y «su parte de casa, pozo, era y ejidos para laboreo», generando 2363 reales anuales en su conjunto. Junto a las fincas también poseía dos mulas en labor, dos yeguas, veinte ovejas de vientre y dos cerdos (324 rs.). Entre las cargas que soportaba debía pagar un total de 392 reales de pensiones de censo a diferentes personas, conventos y memorias y 230 reales por el salario y comida de una criada.

Por otro lado, Francisco Javier de Vera, junto a los 880 rs. por la escribanía del número de la villa, contaba con un patrimonio urbanístico y rústico escaso. Entre las

\footnotetext{
74. MaraVall, J.A.: Estado Moderno y mentalidad social. Madrid, 1972. T. II. Pp. 35-36.

75. EXTREMERA EXTRemera, Los escribanos públicos de Córdoba... op. cit. p. 105.

76. Gregorio Martínez Arenas desempeñaría el oficio de escribano del número propiedad de su padre Juan Martínez a partir de 1785, por lo que en estos momentos, posiblemente estuviese empleado tan sólo como oficial o aprendiz en la escribanía.
} 
Tabla 1: Escribanos que se reflejan en el Catastro de Ensenada

\begin{tabular}{|c|c|c|c|}
\hline NOMBRE & FAMILIA & PROFESIÓN & $\begin{array}{l}\text { INGRESOS } \\
\text { Rs. anuales }\end{array}$ \\
\hline $\begin{array}{l}\text { DIEGO GÓMEZ DEL } \\
\text { CASTILLO }\end{array}$ & Casado sin hijos. & $\begin{array}{l}\text { Escribano de millones } \\
(500) \text {. } \\
\text { Interventor del correo } \\
(1100) \text {. } \\
\text { Administrador del benefi- } \\
\text { cio de San Fulgencio. }\end{array}$ & 1830 \\
\hline $\begin{array}{l}\text { JOSÉ LUCAS } \\
\text { MARTÍNEZ }\end{array}$ & Viudo dos hijas. & $\begin{array}{l}\text { Escribano del número } \\
(250) . \\
\text { Escribano de ayuntamiento } \\
(1100) \text {. }\end{array}$ & 1350 \\
\hline $\begin{array}{l}\text { JUAN MARTÍNEZ } \\
\text { ARENAS }\end{array}$ & & Escribano del número. & 1100 \\
\hline MARTÍN PERAL & $\begin{array}{l}\text { Casado cuatro hijos } \\
\text { menores. }\end{array}$ & Escribano del número. & 850 \\
\hline $\begin{array}{l}\text { ANTONIO JOSÉ } \\
\text { MARTÍNEZ }\end{array}$ & $\begin{array}{l}\text { Casado cinco hijas y } \\
\text { un hijo menor de } 18 \\
\text { años. }\end{array}$ & $\begin{array}{l}\text { Escribano del número } \\
\text { bajado } 250 \text { rs. que paga a } \\
\text { la villa. }\end{array}$ & 800 \\
\hline $\begin{array}{l}\text { FRANCISCO JAVIER } \\
\text { DE VERA }\end{array}$ & Casado sin hijos. & $\begin{array}{l}\text { Escribano real y escribano } \\
\text { de ayuntamiento. }\end{array}$ & 800 \\
\hline $\begin{array}{l}\text { FRANCISCO } \\
\text { ANDUJAR }\end{array}$ & Casado un hijo. & Oficial de escribano. & 360 \\
\hline JOSÉ VILA & & Escribano real. & 360 \\
\hline PEDRO DE OREA & Casado tres hijas. & $\begin{array}{l}\text { Escribano del número y de } \\
\text { ayuntamiento que no utili- } \\
\text { za. Contador (330). }\end{array}$ & 330 \\
\hline $\begin{array}{l}\text { GREGORIO } \\
\text { MARTIINEZ ARENAS }\end{array}$ & $\begin{array}{l}\text { Casado dos hijos } \\
\text { menores. }\end{array}$ & Escribano & 220 \\
\hline
\end{tabular}

primeras, tan sólo poseía la cuarta parte de una casa en la calle Mayor, valorado su alquiler en 55 rs. Y en cuanto a fincas rústicas, 3,8 Ha. repartidas entre viña y labradío de secano, todas en la redonda de la villa, y que le reportaban 565 rs. También, como en el caso anterior debía hacer frente al pago de pensiones con un total de 86 reales anuales.

Todo ello nos ofrece una muestra de la falta de homogeneidad ${ }^{77}$ de este grupo que se refleja en su extremo inferior con escribanos modestos, con escasos recursos económicos, que incluso llegan a solicitar al ayuntamiento que se le perdone o releve la

77. Estas diferencias han sido calificadas como vergüenza de la pobreza y privilegiados por GoNZÁLEZ CRUZ (Escribanos y notarios en Huelva durante el Antiguo Régimen (1701-1800). Huelva, 1991. p. 70) y señaladas también por CUESTA MARTÍNEZ, (Oficios públicos y sociedad. Op. cit. p. 415). 
paga de los 250 reales de la pensión ${ }^{78}$; y en su parte superior, por un fulgurante ascenso social de otras pocas familias que llegan incluso a ocupar regidurías. Era un largo proceso en el ascenso socio-económico al que podían optar estos personajes desde un extremo a otro, a lo largo de toda su trayectoria profesional. Esta adscripción se hace tanto en función de sus características socio-económicas, más lucrativas, como de la sensación de poder, dignidad y honra que se encontraba intrínseca al oficio que se desempeñaba. De hecho, con el paso del tiempo no sólo los encontraremos ejerciendo únicamente su oficio de escribano, sino que también aparecerán como candidatos a las alcaldías de la Santa Hermandad, procuradurías, y también, en las nuevas figuras creadas durante el reinado de Carlos III -diputados y personeros-, donde desempeñarán un papel relevante. ${ }^{79}$ Algo similar ocurre en Lleida donde Passola Tejedor ${ }^{80}$ los coloca -como notarios-, a la cabeza de los profesionales de la mano media, al igual que Elliot ${ }^{81}$ que los llega a identificar como alta burguesía junto a mercaderes, abogados, doctores y aristocracia urbana.

\subsection{Familia, configuración de grupos, ascenso social y relaciones}

En un municipio de corto vecindario como era Albacete, fue inevitable que surgieran compactas tramas familiares, tanto por vínculos de sangre como por afinidad, provocando el nacimiento de verdaderos «monopolios familiares ${ }^{82}$. De hecho era frecuente la herencia de clientelas y redes sociales que permitiesen -a juicio de Extremera $^{83}$ - rentabilizar y materializar la antigüedad y por tanto el éxito de una escribanía.

78. En el mes de junio de 1702 Gregorio Francisco Martínez presentaba una petición al ayuntamiento exponiendo que en las cuentas que se habían tomado al mayordomo de propios se había expuesto que debía 250 reales de la pensión del año anterior, y solicitaba que se le rebajase esa cantidad por haberse incorporado el 15 de julio y no haber estado ejerciendo durante todo el año. Esta situación se repetiría en agosto de 1706 cuando, solicitaba que se le perdonase o relevase la paga de los 250 reales de la pensión, a lo que los capitulares respondieron que se le retrasase el pago hasta el día de las elecciones. A.H.P. de Albacete. Sec. Municipios. Libro 85.

79. Véase GUILlAMÓN ÁlVAREZ, F J. y LOSA SERRANO, P., «Absolutismo ilustrado y administración local (estado de la cuestión de la reforma de 1766): elecciones de diputados del Común y Síndico personero de la Villa de Albacete (1766 - 1817)» en Actas del Coloquio Internacional «El mundo hispánico en el siglo de las luces», Tomo II, Madrid, 1996; y CóZAR GuTIÉRreZ, R.: «Los nuevos cargos del ayuntamiento: análisis del proceso electoral de los diputados del común y síndicos personeros en la villa de Albacete (1766-1817)» en Reformistas y reformas en la administración española. Madrid, 2005. pp. 373-392; Id. Gobierno municipal y oligarquías... op. cit.

80. Passola I Tejedor, A.: Oligarquía, municipio y corona en la Lleida de los Austrias. Tesis doctoral, Lleida, 1995. p. 280.

81. ElLIOT, J.H.: La Rebelión de los Catalanes. Madrid, 1982. p. 127.

82. CANELlas LóPEZ, A., «El notariado en España hasta el siglo XIV: Estado de la cuestión», en Notariado público y documento privado: de los orígenes al siglo XIV. Actas del VII Congreso Internacional de Diplomática, I, Valencia, 1989. p. 160

83. EXTREMERA EXTREMERA, La pluma y la vida ... op. cit. p. 194. 
También es de resaltar su función de eslabón entre gobernantes y gobernados que, junto con la propiedad del cabildo municipal de una escribanía del número y la designación de los escribanos del ayuntamiento, condicionaría la formación de los entramados familiares y las redes de relación social de estos «grupos intermedios» y tendría su reflejo en la composición de las banderías capitulares, generando no pocos problemas. Resulta evidente que todos estos personajes se unieron mediante relaciones familiares, económicas o de comunidad de intereses para servir y reforzar a los grupos de poder y sólo unos pocos, como en el resto de grupos sociales, conseguirían el anhelado ascenso social en un ejemplo de lo que Maraval1 ${ }^{44}$ llamó «movilidad ascendente por goteo».

Pretendemos mostrar a continuación el ejemplo, a modo de prosopografía o biografía colectiva, de dos familias con dedicación a la escribanía, con trayectorias vitales similares en cuanto a su movilidad social y acaparación de títulos y patrimonio, pero contrarios y enfrentados en muchas ocasiones por su pertenencia a una red de relaciones determinada. Nos referimos a la familia Orea y a los Navarro.

Antonio de Orea es uno de los escribanos que aparece al iniciarse el Setecientos. Bautizado en la iglesia de Santa María de la Esperanza de la cercana villa de las Peñas de San Pedro el 14 de febrero de 1661, su padre, Pedro Orea contraería matrimonio con María Felipe, emparentada con una de esas familias "principales de la república», lo que le posibilitaría los bienes necesarios para ofrecer estudios a algunos de sus hijos. ${ }^{85}$

Tras obtener el nombramiento de escribano público, presentó su título en la villa, donde entraría a formar parte de los escribanos del número y también como escribano de ayuntamiento, aunque no sin problemas. En las elecciones de oficios de $1703^{86}$ a la hora de la designación de escribano de ayuntamiento se tuvo que proceder a realizar una votación particular de cada uno de los capitulares, por no estar de acuerdo algunos de ellos en la reelección como tal de Bartolomé Navarro de Toledo, que lo venía ejerciendo durante algunos años. La votación otorgaría una mayoría aplastante a favor de Antonio de Orea regulando que «en caso que haya de asistir a las dependencias del cabildo acompañado es su voto y parecer que lo sea de Bartolomé Navarro y Toledo por las razones que le asisten y que es por haber cumplido con su obligación en las ocasiones que lo ha sido entre a servir dicha escribanía».

$\mathrm{Su}$ actitud frente al resto de escribanos no fue positiva. Después de su designación, el 10 de noviembre de ese mismo año, presentaba una queja formal ante los capitulares alegando que no era su intención servir en el ayuntamiento acompañado por otro escribano, lo que ocasionó un problema que los regidores no dudaron en resolver de una manera directa: volver a nombrar a Bartolomé Navarro como único escribano del ayuntamiento y destituir al Sr. Orea. Curiosamente, después de estos problemas y,

84. Maravall, J.A.: Poder, honor y élites en el siglo XVII. Madrid, 1979. p. 129.

85. La familia Orea aparece unida en principio al trato al por menor de productos de consumo como carne, tocino y bajocas. y a las profesiones liberales, pero después se acomodaron en la renta de sus fincas rústicas. Gómez CARRASCO, C.: La comunidad mercantil en la villa de Albacete. Familia, crecimiento urbano y desarrollo comercial (1680-1830). Cuenca, 2008. p. 329.

86. A.H.P. de Albacete. Sec. Municipios. Libro 85. 
posiblemente como represalia, ya no volvería a ser nombrado escribano del ayuntamiento hasta $1708 .{ }^{87}$

Éste no sería el único oficio que poseyera. A principios de siglo aparece continuamente designado como «fiel de carnicerías» con la función de administrar y vigilar las carnicerías y los estancos. Un oficio que le pertenecía en propiedad con la consideración de poder nombrar tenientes, pero que la villa debía corroborar anualmente en las elecciones de oficios, lo que provocará algunos problemas en las sucesiones posteriores.

El 5 de junio de $1701^{88}$ presentaría en el ayuntamiento el nombramiento de contador de cuentas y particiones perpetuo con los cometidos -como su propio nombre indica- de hacer cuentas y particiones, repartir dehesas y heredades, así como liquidar cartas ejecutorias, mayordomías, asientos, administraciones y contratos. En contrapartida, le estaba vedado el realizar las cuentas de propios y las del pósito. ${ }^{89}$

En enero de $1706^{90}$, presentaría una certificación en la que aparecían todas las cuentas que tocaban en relación del derecho de los servicios de carnes y tres millones, y un año después, en el mes de mayo de 1707, obtenía un nuevo título, esta vez, como escribano de los servicios de millones en lugar de García Ranjel. ${ }^{91}$

87. También en unas elecciones marcadas por la polémica y que concluyeron en votación, Diego de Sagarraga, que era el primero en votar, dio su voto a Bartolomé Navarro y Antonio de Orea. Voto con el que el resto de capitulares que estaban presentes no se conformaron procediéndose a la elección. El Sr. Sagarraga votaría en primer lugar a Antonio de Orea «por su mucha inteligencia» y después a Bartolomé Navarro. Alonso Espinosa se conformaría con el parecer del anterior añadiendo «que si Antonio de Orea no pudiese asistir por algún accidente es de sentir se quede sólo el presente (Bartolomé Navarro)». A estas posturas se unieron Francisco Núñez, Francisco Munera y Jerónimo Navarro. Por otro lado Andrés de Cantos expondría "que respecto de haber corrido en la escribanía de ayuntamiento diferentes años Bartolomé Navarro es de parecer por haber cumplido con su obligación se quede en dicha escribanía de ayuntamiento y que respecto de ser preciso que los demás se vayan habilitando para poder ejercer dicha escribanía es de dictamen le acompañe en ella Gregorio Francisco Martínez quien hasta aqui no lo ha sido». A esta opinión se unirían Juan Fernández, Pedro Carrasco y Gines de Cantos, por lo que resultaría elegida la proposición del Sr. Sagarraga tan sólo por un voto de diferencia, que sería el de Jerónimo Navarro que, curiosamente, se presentaría a la votación cuando ésta estaba a punto de concluir. A.H.P. de Albacete. Sec. Municipios. Libro 86.

88. A.H.P. de Albacete. Sec. Municipios. Libro 85.

89. En Cáceres en el siglo XVII el contador numerario servía a la villa llevando cuentas durante tres días semanales, por los cuales se le pagaba la cantidad de doce reales a la semana. SÁnCHEz PÉREZ, Poder municipal y oligarquía... op. cit. p. 63.

90. A.H.P. de Albacete. Sec. Municipios. Libro 86. Anexo en el inicio del libro.

91. El cometido de este oficio quedaba descrito con minuciosidad en el título: «mando que ante vos... se hagan como dicho es autos, negocios y causas civiles y criminales tocantes a los dichos servicios y otorgarse los arrendamientos, acuerdos, registros, informaciones y dar testimonios de sacas de los géneros de que se causa la sisa que se sacare de la dicha villa de Albacete para consumir en otros lugares; y asimismo hayan de pasar y hacerse ante vos todas las fieldades de sisas y medios aplicados para la paga de los dichos servicios y que se aplicaren adelante y comisiones para cobrar lo que todo ello se debiere en la dicha villa de Albacete y para todas otras cualesquier cosas que toquen al citado servicio y los autos que se hicieren en las comisiones que en cualquier manera el Reino o su comisión de la 
Entre los años 1715-1719 deja de aparecer como escribano del número y de ayuntamiento quedando únicamente encargado del fielato de carnicerías. En estos años se produce el traspaso de la escribanía a su hijo Pedro de Orea Hergueta quien aparece, por primera vez en las actas capitulares en las elecciones de oficios del año $1720^{92}$ en las que sería designado como suplente en la del concejo, en la que actuaba como titular Fernando Jiménez. Curiosamente, en ese mismo año ejercería en trece ocasiones antes de tener ese nombramiento. En estas elecciones también será elegido como escribano del número de la villa. La falta de las actas capitulares nos priva de seguir con exactitud la sucesión de esta escribanía. Sin embargo, el inventario de los protocolos notariales que concluyen en el año 1717 para Antonio de Orea nos hacen suponer que fue éste el año en el que renunciaría a la escribanía, quedándose tan sólo con los títulos de contador del número y el fielato de carnicerías que continuó ejerciendo hasta 1726. El traspaso entre padre e hijo también resulta evidente, pues será el único cambio en las escribanías en estos años.

La trayectoria profesional de ambos será muy similar. Como ya hemos visto, el padre recogió diferentes oficios públicos, que poco a poco, fue trasmitiendo al hijo. Así pasó con la escribanía del número que se traspasarían en 1717, la escribanía de millones a finales de ese mismo año, y también, con el título de contador y el fielato de carnicerías.

A pesar de la aparición en las escribanías de Pedro de Orea, ya en la primera mitad del siglo, Antonio mantendría su oficio como contador del número y fiel de carnicerías hasta 1726, año en el que el hijo obtendría su título real como contador de cuentas y particiones, pasando, también, a ejercer como fiel.

Al igual que ocurrió con su padre, su elección como escribano del concejo también se vio envuelta en polémica. En unas elecciones ${ }^{93}$ en las que casi todos los oficios se sometieron a votación, el alférez Francisco Carrasco comenzó eligiendo a Pedro de Orea, relevándole de la paga del arrendamiento de la del número conforme a la costumbre, a cuyo voto se unieron todos los demás regidores, excepto Juan de Espinosa y Andrés de Cantos quienes nombraron a Fernando Jiménez de la Cárcel, exponiendo que el nombramiento se debía de hacer por unanimidad y de lo contrario se quejarían ante el Consejo por no cumplirse con la legalidad. El alcalde mayor acataría los votos de la mayoría y el Sr. Orea entraría de esta manera en el ayuntamiento apoyado por este grupo mayoritario.

A partir de este instante asistirá en 457 ocasiones de 743 posibles hasta 1760, aunque a los pocos años de entrar ${ }^{94}$ solicitaba que se le eximiese del cargo de escribano de ayuntamiento por las muchas ocupaciones que tenía en esos momentos y que, recorde-

Administración de Millones en su ausencia despacharen o se hicieren en la dicha villa...» A.H.P. de Albacete. Sec. Municipios. Libro 86. Ayuntamiento de 13 de mayo de 1707. Real título de escribano de millones en manos de Antonio de Orea.

92. A.H.P. de Albacete. Sec. Municipios. Caja 243.

93. A.H.P. de Albacete. Sec. Municipios. Libro 90. Ayuntamiento de 29 de septiembre de 1737.

94. A.H.P. de Albacete. Sec. Municipios. Libro 90. Ayuntamiento de 4 de enero de 1738. 
mos, eran las de escribano del número, del concejo, de millones, contador del número, fiel de carnicerías y tesorero de arbitrios y dehesas. Los capitulares harían caso omiso a esta sugerencia obligándole a que siguiese en el cargo e instándole a que más adelante se le darían providencias. Todos los regidores, excepto Andrés de Cantos que aceptaba esta petición motivado más por expulsarlo del concejo que por acceder a sus favores.

En las décadas centrales del siglo comenzará a deshacerse de algunos de sus títulos y a conseguir otros de mayor capital social. El 25 de junio de $1740^{95}$ se presentaría en el consistorio un real titulo de escribano de millones a favor de Diego Gómez del Castillo, en lugar de Pedro de Orea. En los años siguientes, aunque desaparece de las sesiones capitulares ${ }^{96}$, mantendrá su influencia en el ayuntamiento, ya que, como nos informa en su respuesta número 28 el Catastro de Ensenada, el Sr. Orea era poseedor de uno de los oficios de regidor enajenados que tenía arrendado a Gil Fernández Cortés. Luego había preferido seguir ocupando su cargo como escribano, que no le impedía compatibilizar otros como el de contador, fiel, etc., a ejercer el oficio de regidor, que aunque con más poder no le reportaría mayores beneficios económicos. De esta manera, añadiría a esos ingresos, los que obtuviese de «arrendar» este oficio, y con su presencia en los ayuntamientos como escribano, al igual que el poseedor de su oficio de regidor, quedaba asegurada también su influencia.

En el año $1760^{97}$ solicitaba al ayuntamiento que se le nombrase un teniente ya que los muchos accidentes que tenía no le permitían ocuparse con el celo debido de su oficio, a lo que la villa accedería nombrando como su teniente a Francisco de Vera. De esta manera se vislumbra como la actividad del Sr. Orea estaba llegando a su fin. De hecho, el Libro de Vecindario del Catastro de Ensenada nos informa de su avanzada edad de más de 70 años. ${ }^{98}$ Por tanto, el consistorio comenzaría a preparar su sustitución en los diferentes oficios que desempeñaba. En 1762 Pedro de Orea presentaba un memorial a los capitulares en que exponía su deseo de dejar la escribanía del ayuntamiento "por tener mucho accidentes y que se nombre en su lugar por interino a Francisco de Vera». ${ }^{99}$ Sin embargo, en unas elecciones de oficios marcadas por una gran conflictividad entre los bandos capitulares ${ }^{100}$, primaría la opción del bando contrario, designando finalmente a Juan Martínez Arenas en lugar de Francisco de Vera.

\footnotetext{
95. A.H.P. de Albacete. Sec. Municipios. Libro 91.
}

96. En las elecciones de oficios de 1748 un grupo reducido de capitulares -Francisco Munera, Andrés de Cantos y Juan de Espinosa- no estaban muy de acuerdo con su elección, alegando que «se halla impedido con diferentes achaques habituales y este por ellos no poder asistir a todo lo necesario del oficio de ayuntamiento de esta villa por que lo mas del tiempo del año esta en cama».A.H.P. de Albacete. Sec. Municipios. Libro 92. Ayuntamiento de 29 de septiembre de 1748.

97. A.H.P. de Albacete. Sec. Municipios. Libro 95. Ayuntamiento de 17 de septiembre de 1760.

98. A.H.P. de Albacete. Sec. Municipios. Caja 734.

99. A.H.P. de Albacete. Sec. Municipios. Libro 95.

100. Losa SERrano, P. y CózAr GutiÉRrez, R.: «Las luchas oligárquicas y sus consecuencias en el gobierno municipal de Albacete durante la Edad Moderna», en Revista de Historia Moderna, no 19 (2001). pp. 385-402; Id. «Dificultades de la villa de Albacete para ejercer su jurisdicción ordinaria en el Antiguo Régimen», Actas del II Congreso de Historia de Albacete, Albacete, 2002. 
A la hora de elegir escribanos del número, y vista la derrota en la designación anterior, los Carrasco expusieron que debían seguir los mismos del año anterior por no existir ninguna vacante, a lo que los otros respondieron que, por los muchos accidentes «junto con su avanzada edad de 70 años poco más o menos, le tienen en la miserable constitución de no poder salir de su casa pasando la mayor parte del año en la cama... dando lugar a que no este servido el juzgado como no está», por lo que solicitaban que se diese cuenta al Consejo «a fin de que se digne declarar por vacante la citada escribanía». Por lo tanto, quedaba este acuerdo en suspenso, dando poder, poco tiempo después, para que el Consejo declarase vacante la escribanía de Pedro de Orea. Pero no lo conseguirían, pues la seguiría ejerciendo hasta 1767, año en el que falleció.

Finalmente, también se enfrentarían con motivo de la elección del fielato de carnicerías. Los Carrasco nombraron a Pedro de Orea

«respecto de que le consta a este ayuntamiento que lo esta sirviendo por él su hijo Francisco Javier Orea y que no ha habido la menor queja en el romaneo y que a los que exponen les consta tiene ganada una Real Provisión del Real y Supremo Consejo de Castilla con oposición de siete regidores en que manda a la Real Justicia de amparo en la posesión por el señor d. Agustín Lozano, alcalde mayor, en el año pasado de 1757».

El resto de capitulares intentarían desproveerle de este nombramiento argumentando, en primer lugar, que este oficio era propio de la villa «mediante a la costumbre y regalia que tiene de ejecutarlo anualmente habiendo sido así de inmemorial y en el año antecedente en el referido Pedro Orea quien lo aceptó así en el como en otros en que se ha hallado presente por lo que se extraña con qué motivo haya obtenido la Real Provisión que no se ha hecho saber a este ayuntamiento y cita el señor Antonio Carrasco y consortes». Y en segundo, señalaban la incapacidad del Sr. Orea, que le hacía estar totalmente impedido para la asistencia de ese encargo. De esta manera, dejarían este nombramiento suspenso.

En el mes de febrero ${ }^{101}$ de ese mismo año, se solicitaría un informe sobre la vida y costumbres de Martín del Peral que había solicitado el oficio de contador de Pedro de Orea, a lo que los capitulares pondrían muchos impedimentos, señalando que esta renuncia era una treta del Sr. Orea para continuar ejerciendo el oficio de contador y el fielato de carnicerías, acusando a Martín del Peral de ser un «agente descubierto» en el pleito que estaba siguiendo la villa contra los Carrasco -cabezas del grupo al que pertenecía Orea- por el señorío de Pozo Rubio. Por lo tanto, esta sustitución quedaría también suspensa. En el mes de marzo ${ }^{102}$, el Sr. Orea presentaría una Real Provisión a su favor sobre amparo de la posesión del fielato de las carnicerías, y en el mismo día de su recepción, los capitulares dieron poder al agente de la villa en la Corte, Joaquín de Larco y Santelices, para que «convenga y pida el tanteo y consumo de dicho oficio y titulo de contador por el precio de su primera compra el que darán y pagarán de

101. A.H.P. de Albacete. Sec. Municipios. Libro 95. Ayuntamiento de 22 de febrero de 1762.

102. A.H.P. de Albacete. Sec. Municipios. Libro 95. Ayuntamiento de 11 de marzo de 1762. 
sus propios caudales y lo pondrán en esta villa en poder de la persona que por Su Majestad y dichos señores se mandase».

En los años siguientes no se volverá a tener noticia de este pleito. El Sr. Orea seguirá ejerciendo el oficio de fiel de carnicerías hasta el año 1767, y desde ese momento pasaría a ser designado por el concejo, quién primero lo dejaría en manos de los escribanos de ayuntamiento, y en los años finales de siglo, cuando los Carrasco han recuperado su preponderancia en el consistorio, de Martín del Peral

Estos problemas al final de su carrera nos ofrecen mucha información sobre su red de relaciones y pertenencia a los bandos capitulares. Nos decantamos totalmente por su apego al bando de los Carrasco, que a mediados del siglo XVIII se encontraba en minoría y sin un líder destacado, a lo que se sumaban, numerosos conflictos con las titulares del señorío de María Ignacia y Catalina Carrasco. De hecho, un Orea, Ramón Ventura, intentaría la posesión de un oficio de regidor de los pertenecientes a la casa Carrasco, lo que no conseguiría por la oposición del resto de capitulares. ${ }^{103}$

Otra familia destacada en el desempeño de las escribanías será la de los «Navarro». En un principio aparece en la villa dividida en diferentes ramas. Una de las más importantes será la encabezada por Jerónimo Navarro Soriano, regidor, que irá extendiendo sus redes relacionales durante el siglo XVIII, utilizando como principal mecanismo, las alianzas matrimoniales con las principales familias hidalgas del municipio. Una de esas uniones será la realizada con los Cantos, que dio origen a un subgrupo dentro de uno de los bandos oligárquicos: el de los Cantos-Munera.

Bartolomé Navarro, miembro de esta familia, irá consolidando aún más sus influencias con la renovación de sus alianzas matrimoniales con los $\operatorname{Cantos}^{104}$ y la consecución, primero del título de escribano real, y después, de una escribanía perpetua del número que pertenecía al licenciado don Francisco Munera Spuche y Carrasco, presbítero y comisario del santo oficio de la Inquisición del reino de Murcia ${ }^{105}$, y que había vinculado para sus sucesores, pasando finalmente al patrimonio de los Navarro.

Por tanto, al obtener la escribanía perpetua, desaparece del panorama institucional en cuanto a los nombramientos de la escribanía numeraria de la villa, por lo que nos centraremos en su participación en el consistorio como escribano de ayuntamiento. Como tal, lo podemos encontrar ejerciendo como sustituto de García Ranjel a principios de 1701, como único a partir de las elecciones de ese mismo año, y alternándose con los demás hasta 1714. De hecho, de los escribanos que participan en la política municipal de principios de siglo será uno de los que más veces intervenga, con 272

103. A.H.P. de Albacete. Sec. Municipios. Libro 95. Ayuntamientos de 18 de julio y 21 de noviembre de 1761.

104. Según se ha demostrado gracias a los estudios antropológicos, cuando dos familias han contraído una alianza matrimonial, la suelen renovar cuatro o cinco generaciones después, cuando ya la memoria de la misma está a punto de perderse, volviendo a cerrar un «bucle» fácil de detectar en los esquemas genealógicos. DediEU, J.P.: «Familia y alianza. La alta administración española del siglo XVIII» en Sociedad, Administración y Poder en la España del Antiguo Régimen. Granada, 1996. p. 49.

105. A.H.P. de Albacete. Sección Protocolos. Legajo 18. 
asistencias, y más, si tenemos en cuenta, que durante los años 1708 al 1711 no resultaría elegido, en favor de Antonio de Orea y Fernando Jiménez, miembros del bando contrario y predominante en esos momentos en el consistorio.

Aparte de las funciones específicas del oficio de escribano de ayuntamiento durante todo su ejercicio demostró poseer sobrada suficiencia administrativa e incluso jurídica, como demuestran las numerosas comisiones en la que estuvo encargado, que le llevaron a trasladarse a otras localidades como Madrid, San Clemente o Cartagena. ${ }^{106}$

Sus estrechas relaciones familiares con los «Cantos» le harían vincularse al bando capitular que formaban éstos junto a Francisco Munera, lo que explica las enemistades con Antonio de Orea, que era el protegido del bando contrario. Así en 1703, cuando Orea se opone a compartir la escribanía, el bando de los «Cantos-Munera-Villanueva» que prevalecían en número, no sólo no accedieron a sus peticiones sino que nombraron al Sr. Navarro como único escribano.

Pero éste no fue el único enfrentamiento. La conflictividad que se producía en el seno del consistorio entre las capas más altas de los bandos oligárquicos también se reprodujo en su escala inferior, llegando en algunos momentos a hostilidades físicas. El 23 de enero de $1721^{107}$ el alcalde mayor Ambrosio Álvarez de Toledo, a la hora de defenderse de las acusaciones que contra él habían formulado el corregidor de Chinchilla apoyado por algunos regidores (Cantos-Munera-Villanueva), atacó duramente a Bartolomé Navarro a quién acusaba de «haber puesto manos a ciertas personas» lo que había sido ocultado por los escribanos omitiendo de esta forma su «obligación de ejercer las causas».

106. En 1705 (A.H.P. de Albacete. Sec. Municipios. Libro 85) se le otorgaba una carta de poder para que se encargase de diferentes asuntos de extremado interés para el municipio, entre los que se encontraban: la prorroga de los arbitrios para poder pagar los débitos atrasados de 1694; la reducción de los importes del servicio ordinario y extraordinario por haber disminuido la población y por las malas cosechas; lo mismo con el impuesto de milicias; y para que se actuase contra los acreedores del juro de Pedro González Galindo que reclamaban 1600 fanegas de trigo. En esta empresa llegaría a reclamar ante el Consejo, desde donde solicitaba, en octubre de ese mismo año, que se le mandase más dinero para los gastos que estaba teniendo. En mayo de 1711 (A.H.P. de Albacete. Sec. Municipios. Libro 87) volvía a reaparecer designado para una nueva comisión. En esta ocasión se trataba de asistir a la villa de San Clemente para tratar con el corregidor sobre los pagos atrasados e intentar, como en el caso anterior, una rebaja. A principios del año siguiente, se le daba poder para ir de nuevo a San Clemente para tomar cabezón de las rentas de alcabalas, tercias y cientos. En ese mismo año -julio- le volvían a dar otra carta de poder junto a Francisco Vicente Cano para viajar a Cartagena y dar cuentas del estado de los bienes de propios y arbitrios y las cantidades que habían usado en paja, vestuario, bagajes, etc. los ejércitos que habían transitado por la villa, y obtener de esta manera, algún beneficio o rebaja en los impuestos por haber favorecido la causa borbónica. Finalmente en el año 1713 (A.H.P. de Albacete. Sec. Municipios. Libro 87) se dedicaría en exclusiva a tratar sobre el litigio que mantenía la villa con La Gineta por las 1600 fanegas que se debían del situado de Pedro González Galindo de los años 1680 a 1689. El pleito se prolongará desde el mes de marzo hasta agosto, en el que finalmente el Sr. Navarro informó al resto de capitulares que se había llegado a la resolución de que la villa debía pagar 6700 reales, a lo que dictaminaron estar de acuerdo, dando el poder necesario para proceder al pago.

107. A.H.N. Sec. Consejos. Legajo 14. Exp. 15. 
Desde el punto de vista familiar, Bartolomé Navarro tendría, al menos, 4 hijos que conozcamos. ${ }^{108}$ El primogénito fue Francisco Navarro de Cantos que sería en el que recayese, en primera instancia, el oficio de la escribanía, pero que no llegaría a ejercer. Tras su muerte, el oficio, entre otros muchos bienes, pasó a manos del segundo hijo de la familia, Pedro Navarro de Cantos, que como la mayoría de los hijos «segundones» de las familias adineradas -aunque a un nivel inferior-, había iniciado una formación universitaria y administrativa que culminó con su nombramiento como abogado de los Reales Consejos.

El Sr. Navarro presentaría su nombramiento como escribano ante el concejo el 24 de julio de 1754. ${ }^{109}$ En estos momentos la influencia de los Navarro llegó a su cima, pues Pedro Navarro se encontraba sirviendo un oficio de regidor perteneciente a don Fernando del Pando, presbítero de la villa y una vez dentro del consistorio intentó promocionar a su hermano José hasta que finalmente lo consiguió en el año 1761 mediante la compra del oficio de regidor a Juan Espinosa Villanueva. Quedaba pendiente el asunto de la escribanía. Como el desempeño de ambos oficios a la vez era incompatible, pocos meses después de presentar el título en el ayuntamiento, lo dejaba en manos de un teniente: Juan Martínez Arenas.

Nos encontramos con el primer traspaso efectivo extrafamiliar en la escribanía perpetua que poseían los Navarro. El elegido era un personaje que había desempeñado oficios menores como receptor de bulas ${ }^{110} \mathrm{o}$ alcalde de cárcel ${ }^{111}$ y que después pasaría a pertenecer a esa burocracia judicial encabezada por los procuradores del número, oficio que desempeñaría hasta el año 1750 en el que sería sustituido por Martín del Peral.

El 23 de septiembre de $1754^{112}$ presentaba su título en el ayuntamiento. En él se reflejaba el nombramiento real y también su vinculación como propiedad de Pedro Navarro: "mi voluntad es que ahora y de aqui adelante en conformidad del citado nombramiento vos el dicho Juan Martínez Arenas sirváis, uséis y ejerzáis el mencionado oficio de escribano del número de la villa de Albacete como Teniente de dicho d. Pedro Navarro de Cantos». Entre la documentación presentada también se hallaba la razón de la media annata (3022 mrs), una certificación de haber aprobado el examen y el otorgamiento de un signo que debía utilizar en todas las escrituras, autos y «demás instrumentos».

Con este nombramiento no debía someterse a las designaciones del cabildo, aunque curiosamente, también optará a una de esas escribanías, aunque sólo una vez, en el año $1765^{113}$, el único año en el que se nombrarán cinco escribanos en lugar de los cuatro, que eran los que legalmente debían ser elegidos.

108. Francisco, Pedro, José y Mariana Navarro de Cantos, monja del convento de religiosas justinianas de la villa.

109. A.H.P. de Albacete. Sec. Municipios. Libro 94.

110. A.H.P. de Albacete. Sec. Municipios. Libro 90. Ayuntamiento de 26 de febrero de 1737.

111. A.H.P. de Albacete. Sec. Municipios. Libro 91. Ayuntamiento de 25 de junio de 1743.

112. A.H.P. de Albacete. Sec. Municipios. Libro 94.

113. A.H.P. de Albacete. Sec. Municipios. Libro 96. Ayuntamiento de 1 de enero de 1765. 
En el año 1762 se estaba procediendo al traspaso de todos los oficios que ejercía Pedro de Orea por sus graves accidentes y avanzada edad, lo que originó diferentes enfrentamientos. El Sr. Martínez Arenas sería el encargado de sustituirle en la escribanía del ayuntamiento, y desde este momento desempeñaría este oficio junto a José Lucas Martínez, asistiendo a un total de 166 reuniones de las 192 posibles. El 6 de febrero de $1768^{114}$ sería la última vez que apareciese en las reuniones, y en las elecciones siguientes sería sustituido por Martín del Peral.

Pero regresemos a la familia Navarro. Consolidados y multirrepresentados en el ayuntamiento, en 1760 Pedro Navarro iniciaría los trámites para vender el oficio de escribano y el 30 de octubre obtendría una Real Facultad para permutar este oficio por dos hazas de tierras: una huerta en la Hoya de la Morena y otra en la solana del Cerro de la Orca, propiedad de Pedro Tomás Carrasco Ramírez de Arellano y valoradas en 11.000 reales de vellón. Finalmente, Pedro Tomás -hacendado, ganadero y regidor- lo renunciaría el 27 de julio de 1769 de nuevo en Juan Martínez Arenas.

\section{CONCLUSIONES}

Con este trabajo hemos querido analizar al escribano como nexo, mediador y portavoz de la sociedad castellana y su importancia en la vida cotidiana del Antiguo Régimen. Para ello y bajo las pautas de la Historia Social de la Administración, nos hemos centrado, en primer lugar, en el análisis del oficio desde un punto de vista más institucional; en segundo lugar, en el perfil social de este grupo profesional; y, por último, en el estudio de las familias y los «otros parentescos», haciendo hincapié en asuntos tales como la movilidad social y las redes clientelares.

A lo largo de estas páginas hemos observado como en una villa rural en vías de convertirse en una ciudad rural -por su importancia como núcleo comarcal-, la formación y constitución de este grupo profesional quedaba condicionada fundamentalmente por el fuerte proceso de patrimonialización de todos los oficios en el siglo XVI. De ahí que el acceso a una parte importante como eran las escribanías del número estuviese en manos de la familia Navarro y el concejo - que también disfrutaba de la designación de las escribanías de ayuntamiento-, quienes, bien por el desempeño directo de estos oficios o por su arrendamiento conseguían una cantidad considerable de ingresos anuales.

En cuanto al perfil socio-económico se observa cómo los escribanos son un grupo nada homogéneo, en el que podemos encontrar desde aquellos que desempeñan el oficio como manera de subsistir y ganarse la vida, hasta otros más adinerados que mediante la complementariedad con otros oficios, consiguen poseer patrimonios y rentas nada desdeñables. Dentro del grupo observamos que aparece la base necesaria para proporcionar un ascenso social al que sólo llegarán aquellos que mejor sepan utilizar las estrategias y mecanismos de movilidad social. Todo ello bajo el apoyo indispensable de la red de relaciones o clientela a la que pertenecen y su traslado al ayuntamiento con el apoyo de los bandos capitulares, como se puede observar en los ejemplos de las

114. A.H.P. de Albacete. Sec. Municipios. Libro 97. 
familias Orea y Navarro que, aunque las dos conseguirán el anhelado ascenso, sobre todo, socio-económico, su influencia y participación en el ayuntamiento siempre estará condicionado al predominio o no de su bandería. 